\title{
Against the Grain
}

Volume 25 | Issue 5

Article 2

November 2013

Full Page Ads

Follow this and additional works at: https://docs.lib.purdue.edu/atg

Part of the Library and Information Science Commons

\section{Recommended Citation}

(2013) "Full Page Ads," Against the Grain: Vol. 25: Iss. 5, Article 2.

DOI: https://doi.org/10.7771/2380-176X.6598

This document has been made available through Purdue e-Pubs, a service of the Purdue University Libraries. Please contact epubs@purdue.edu for additional information. 


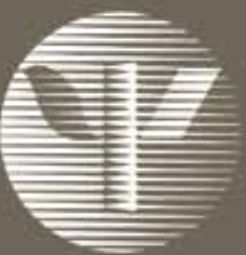

AMERICAN

PSYCHOLOGICAL

ASSOCIATION

PsyciNFO

PSYCARTICLES

PsycBOOKS

PSYCEXTRA:

PSYCCRITIQUES

PsyctESTS

PSYCTHERAPY

APA Books*

E-Collections

\section{APA Handbooks in Psychology ${ }^{T M}$}

APA PsycNET

\section{Access Key Psychology Reference eBooks Through APA PsycNET}

\section{APA Handbooks in Psychology ${ }^{\text {tm }}$ Series}

The APA Handbooks in Psychology Series comprises multiple two- and three-volume sets that address the reference needs of researchers and practitioners in psychology. These reference resources provide undergraduate and graduate students with invaluable supplementary texts, not only for "filling in" their own specialty areas but also for gaining a sound familiarity with central and emerging specialties across the field.
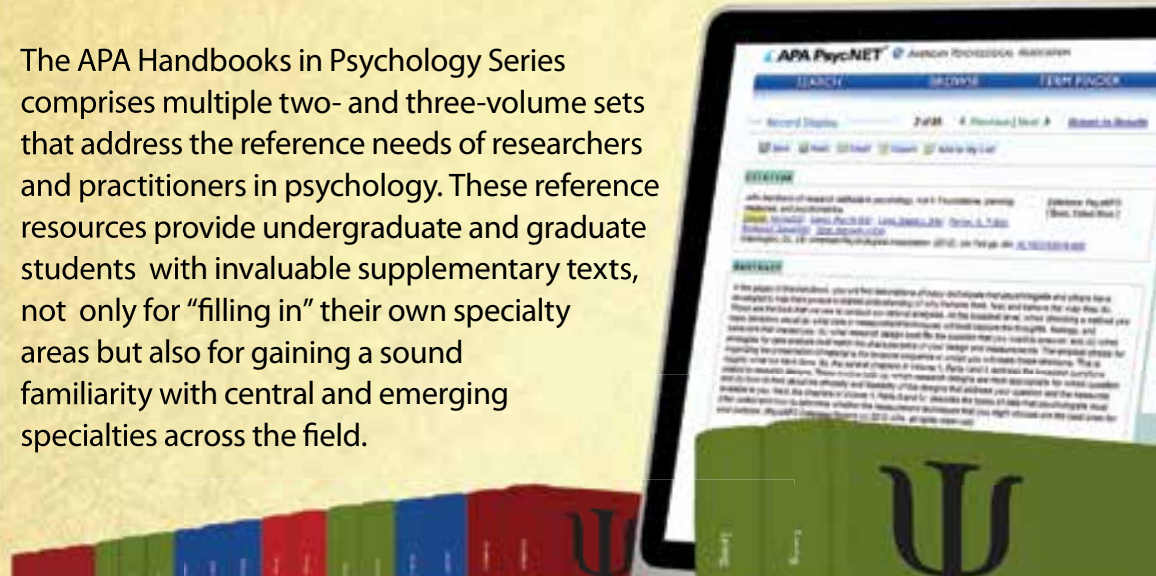

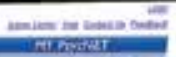

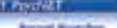

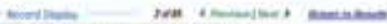

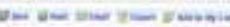
пекен

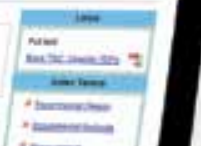
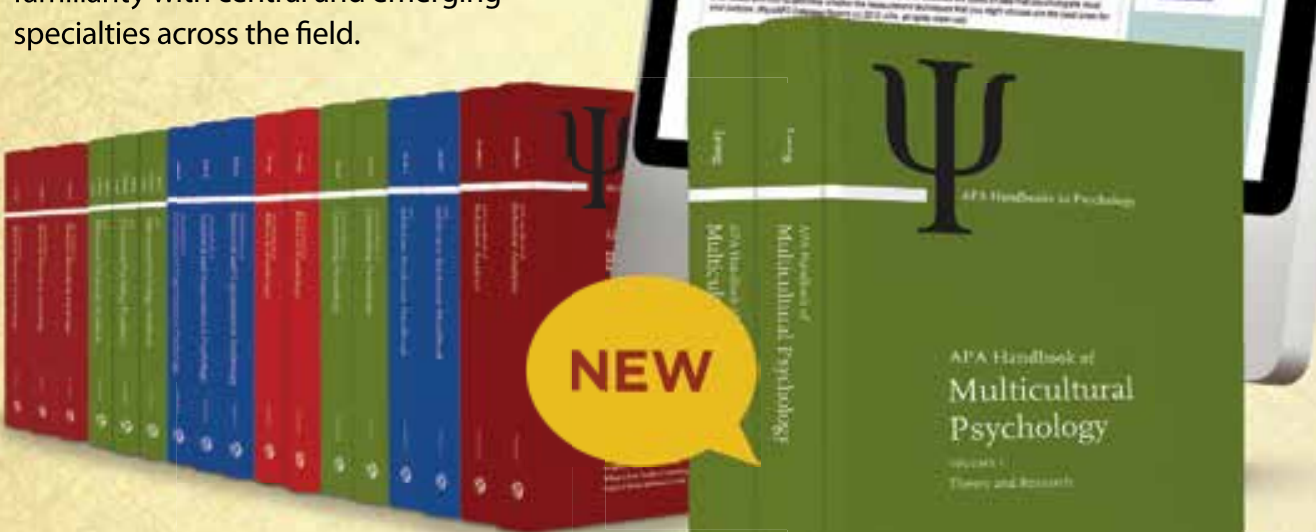

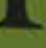

APA Handbooks in Psychology Series:

- APA Addiction

Syndrome Handbook

- APA Educational Psychology Handbook

- APA Handbook of Behavior Analysis

- APA Handbook of Counseling Psychology

- APA Handbook of Ethics in Psychology

- APA Handbook of Industrial and Organizational Psychology

- APA Handbook of Multicultural Psychology

- APA Handbook of Psychology, Religion, and Spirituality

- APA Handbook of Research Methods in Psychology

- APA Handbook of Sexuality and Psychology (New)

- APA Handbook of Testing and Assessment in Psychology

\section{APA Handbook of Multicultural Psychology}

Editor-in-Chief: Frederick T. L. Leong, PhD

Now available for institutional purchase.

The APA Handbooks in Psychology Series is delivered exclusively through APA PsycNET.

For more information or to arrange a FREE 30-DAY TRIAL on APA PsycNET, contact your APA representative, visitwww.apa.org/pubs/marketing/ebooks.aspx call 1-877-236-2941, or email quotes@apa.org. 
Experience. Innovation. Partnership.
COME SEE US AT TABLE \#16 AT THE VENDOR SHOWCASE DURING THE 33RD ANNUAL CHARLESTON CONFERENCE.
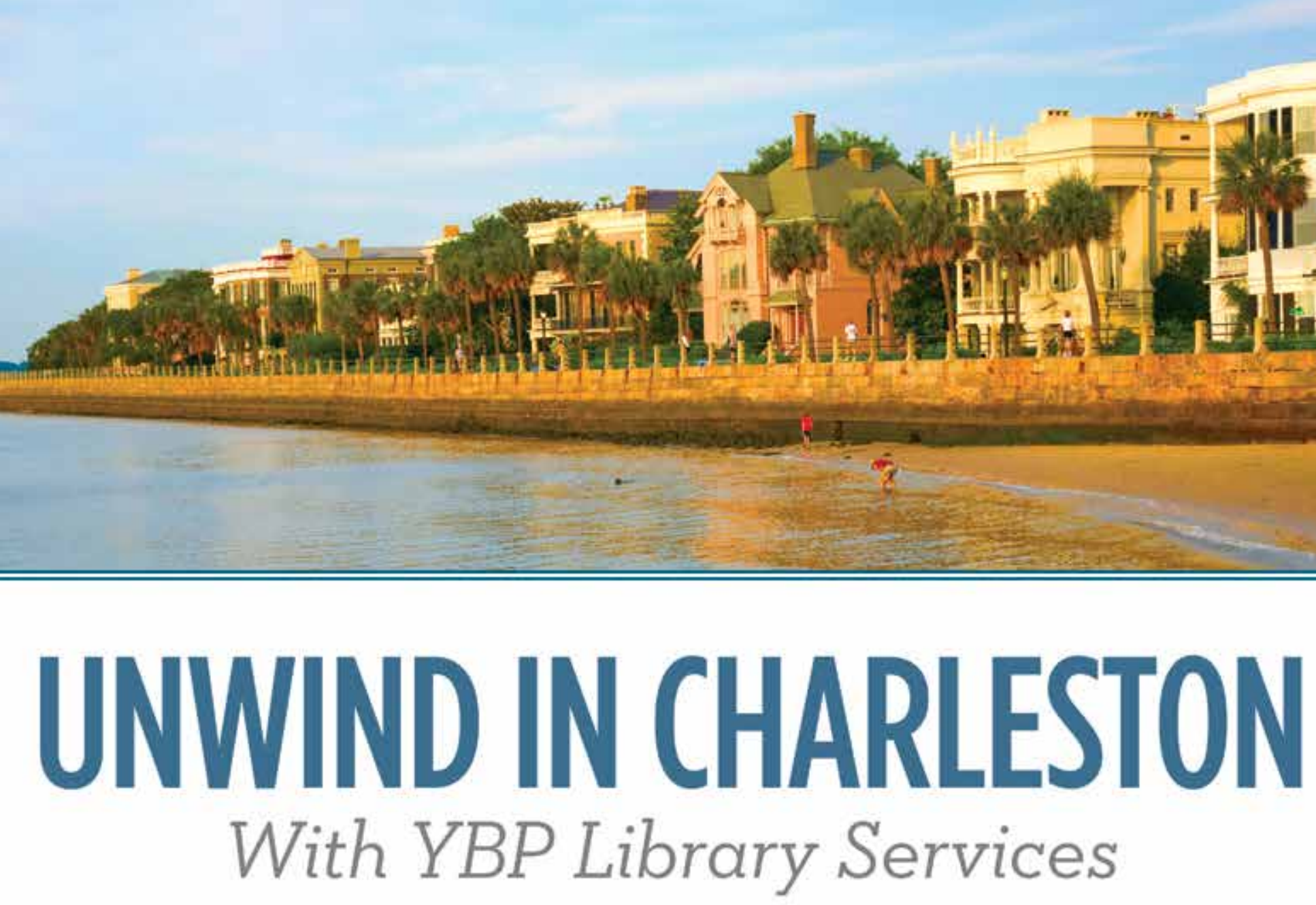

Take a moment to relax at the Charleston Conference - Join YBP's dedicated team for a discussion on how we can provide end-to-end workflow support for your library.

Through partnerships with publishers and content aggregators, YBP offers the most comprehensive integrated digital and print discovery and fulfillment services in the industry. We offer access to more than 10 million noteworthy titles $24 / 7$ in $\mathrm{GOBI}^{3}$ (Global Online Bibliographic Information), our online ordering database.

You can always count on YBP to go above and beyond your expectations to deliver the best of both worlds - content your patrons demand and the services your library needs. 


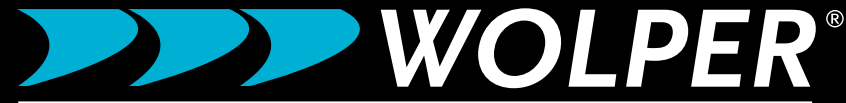

INFORMATION SERVICES
See us in the Pinckney Room at Charleston Conference Vendor Showcase. And, ask us how we can help you with discovery and management of e-resources!

\section{The Perfect Balance}

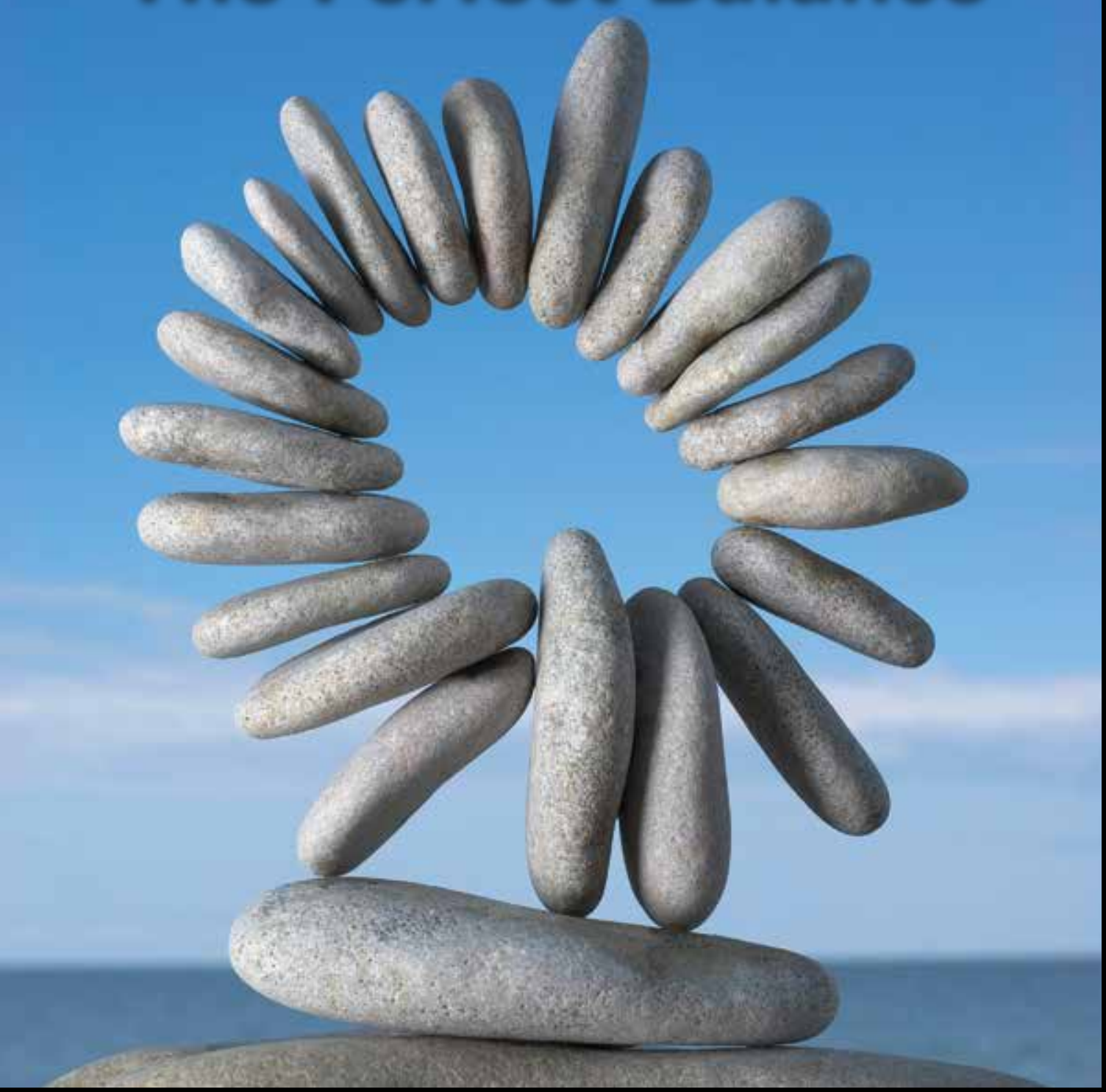

HIGH TECH, High Touch : Next-Gen Technology. Personalized Service.
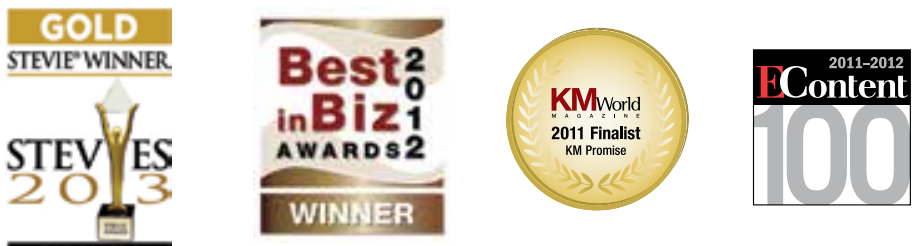

Proud members of:

- American Library Association

- Medical Library Association

- Special Libraries Association

- Association of Subscription Agents \& Intermediaries

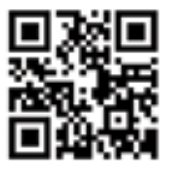

Scan to see the latest on our blog, Insight \& Outlook

We invite you to find out more at www.wolper.com. Please contact us at $\mathbf{6 1 0 . 5 5 9 . 9 5 5 0}$

or inquiries@wolper.com. We're just a phone call or a click away. 


\section{The Future of Discovery at Alexander Street Press}

New! Powerful browsing facets:

zoom straight to the results you're looking for

New! Translate content into 60+ languages

\section{Full-screen viewer: ideal for classroom projection}

New! High-speed streaming adjusts automatically to your bandwidth

Intuitive video editor: create, annotate, and share video clips and playlists formats

\section{New! Export citations instantly in multiple}
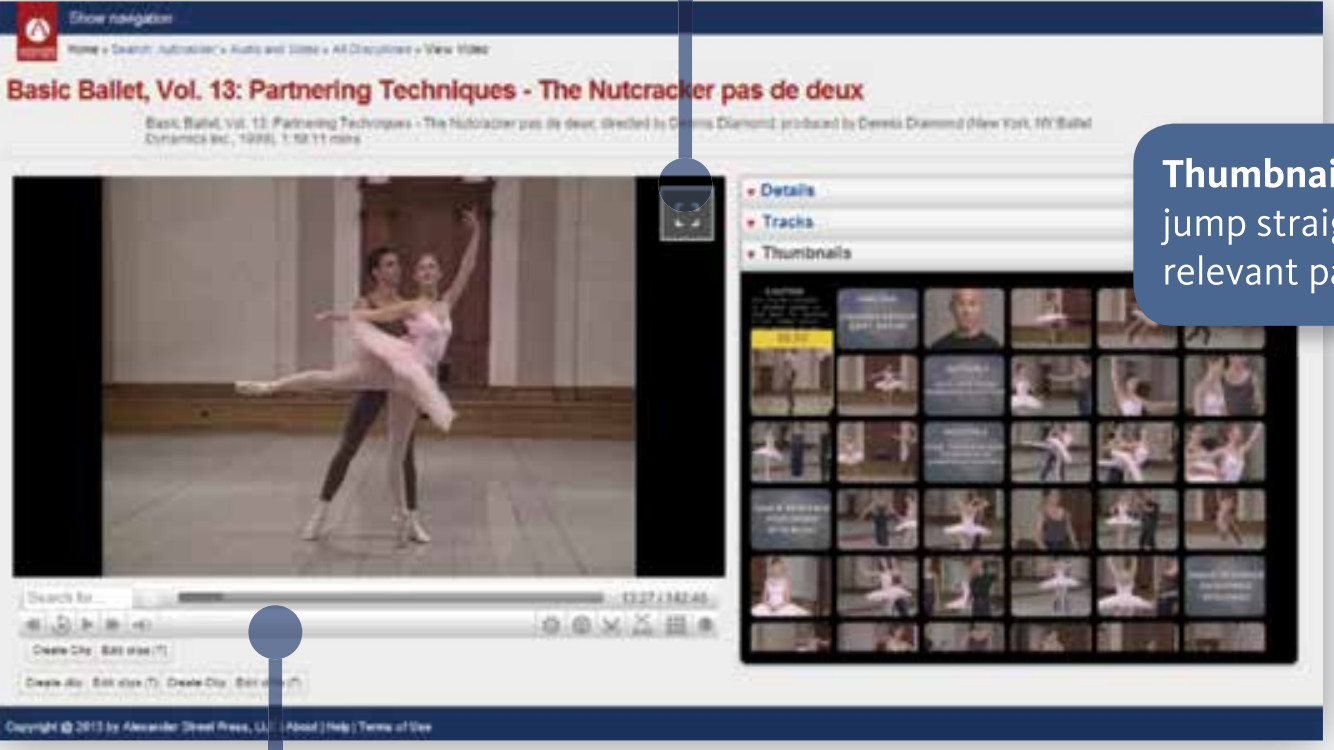

\section{Coming soon!}

Smartphone app for increased mobility

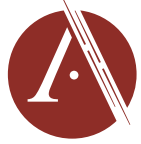

\section{Coming soon!}

Dedicated learning objects: build online quizzes, study guides, timelines, and more.

ALEXANDER

STREET PRESS

\section{Request your FREE 30-day preview today alexanderstreet.com/newfeatpreviewATG}




\section{SWeTs}

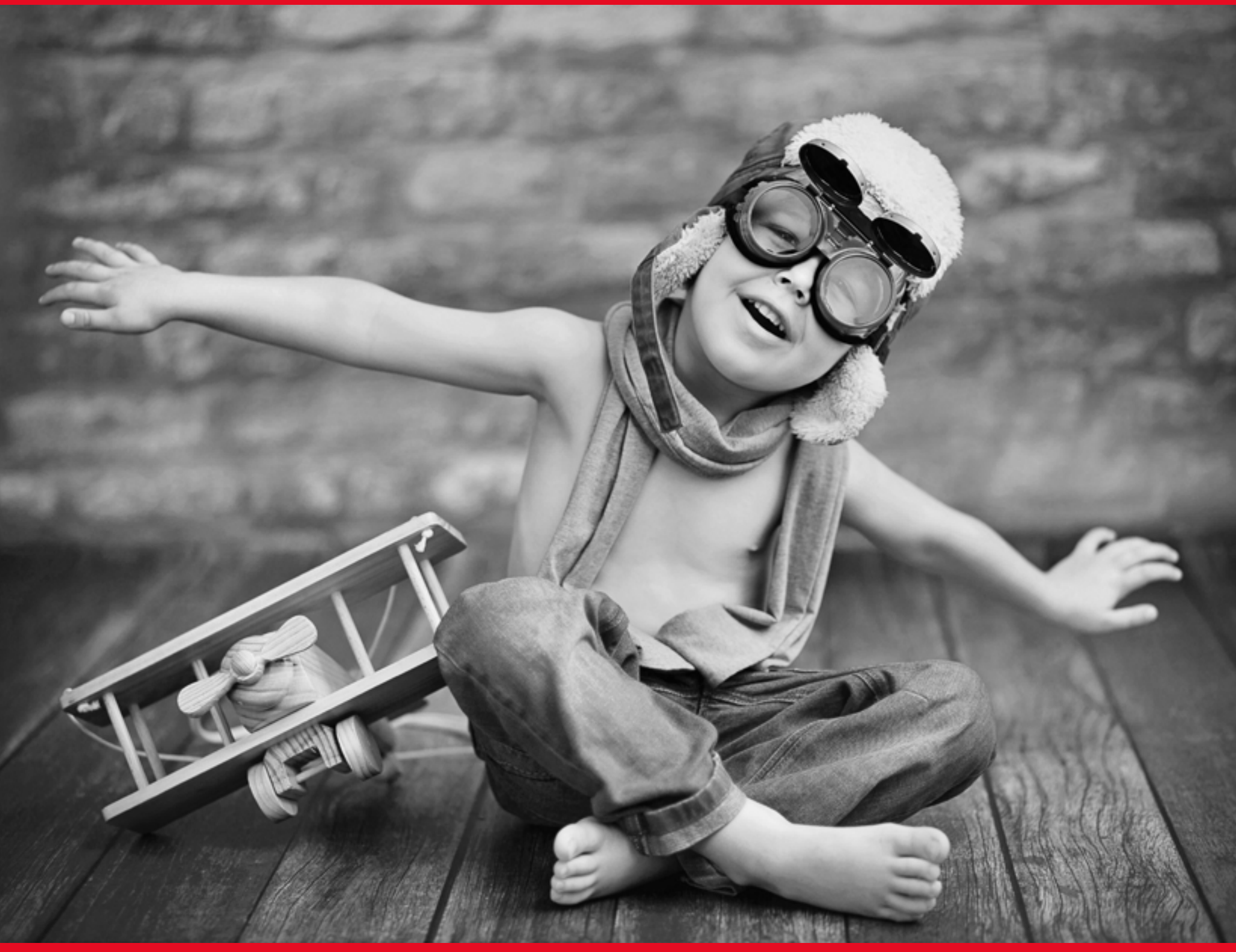

\section{Your Library: Soaring to New Heights.}

COUNTER STATS. ALTMETRICS. JOURNAL. EBOOKS. SEARCH. \& MORE!

Stop by table \#25 at the Charleston Vendor Showcase or visit us online today! 


\section{Empowering Librarians}

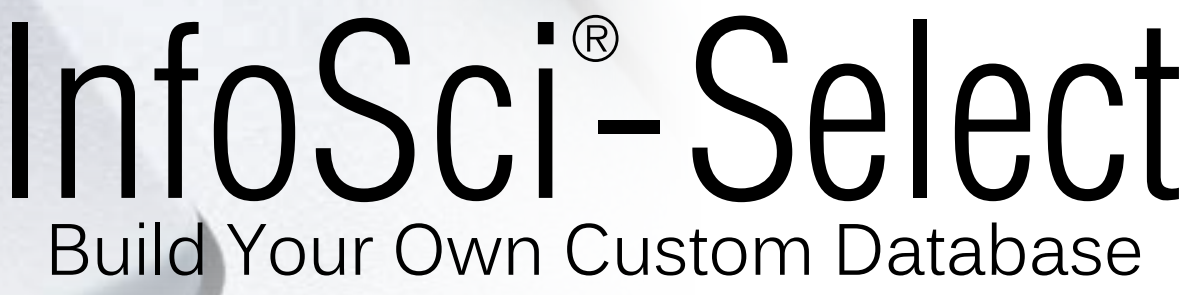

\section{Customizable}

You Choose. Add an unlimited number of titles to one platform to create an electronic database that meets the specific needs of your institution.

\section{Comprehensive}

Make selections from a list of more than 2,000+ premier reference books covering the most cutting-edge research.

\section{Affordable}

Purchase $10+$ titles and receive tiered discounts. Allows you to create a database that aligns with your budget.

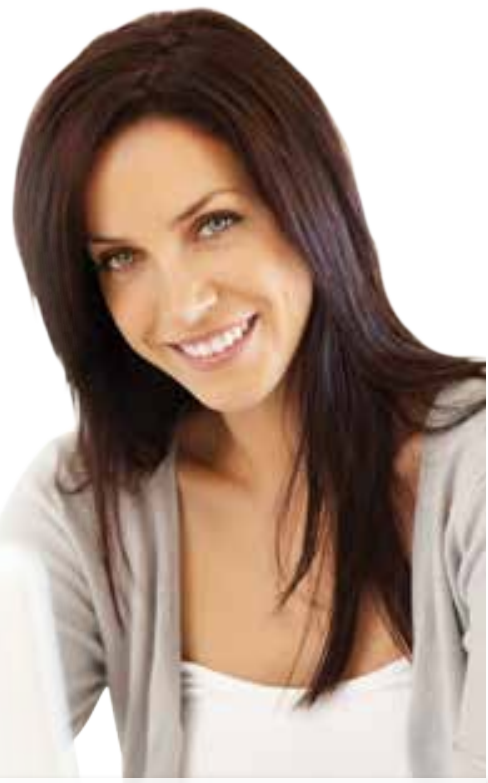

\section{Build Your Database with IGI Global's Recent Content Expansion:}

In addition to publishing titles focusing on the the utilization and management of information science and technology, as it is applied to: education, library science, healthcare, business, public administration, computer science, and engineering. IGI Global is now also pleased to be publishing titles on all aspects of business and management, engineering, healthcare, as well as research in the social sciences, humanities, and natural sciences, INDEPENDENT from information technology.

\section{Utilize the Advanced InfoSci-Platform Features:}

- XML-powered, full-text search

- Increased search speed with ranked results

- Search by content and product type

- Sort by relevance, title, and copyright year

- Spell-check with search suggestions

- RefWorks and EasyBib citation export

- APA-, MLA-, and Chicago-style formatting

- COUNTER compliant reports and statistics
- MARC records to RSS feed

- Persistent URLs

- Liberal DRM

- No maintenance fees

- Supporting SRU industry interoperability standard

- Customize with your institution's logo

- Multi-lingual user interface 
Visit

Today!

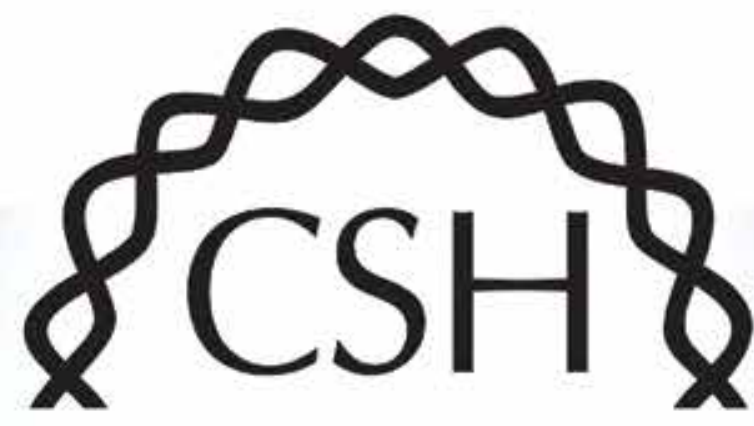

PERSPECTIVES

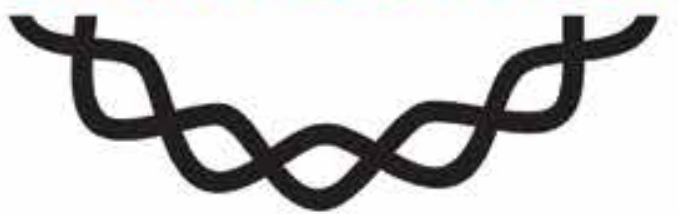

Free

trials

available!

\section{Cold Spring Harbor Perspectives in Biology}

A new type of online review journal

- Spanning the complete spectrum of the molecular life sciences

- Article collections that build month by month

- Written and commissioned by experts in each field

\section{The Authoritative View}

Expert reviews in the molecular life sciences.

\section{www.cshperspectives.org}




\section{OSA's Digital Library}

The largest and most-cited corpus of peer-reviewed content in optics and photonics, hosted on OSA's Optics InfoBase.

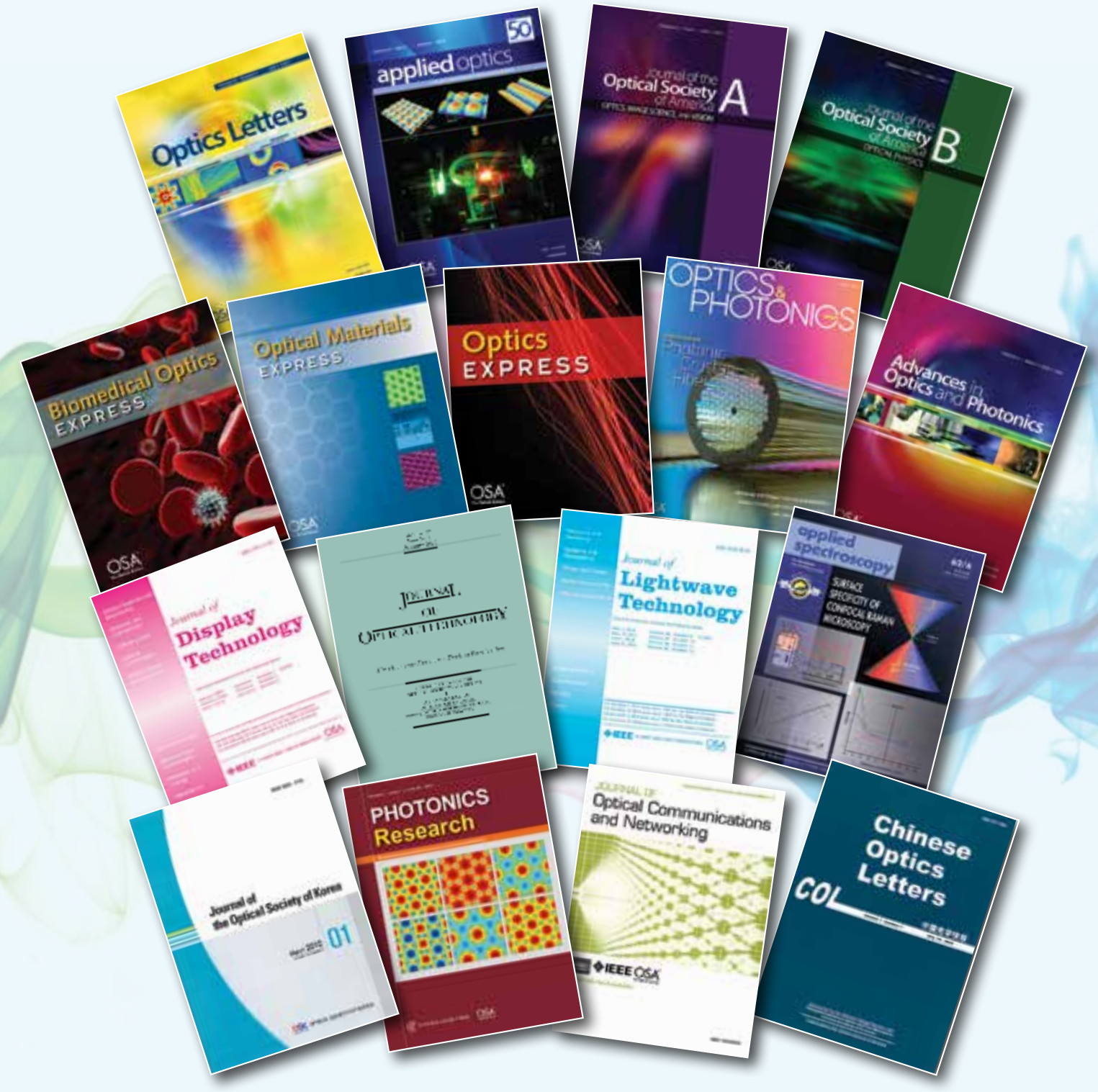

OSA is the nexus for innovators in the optics and photonics field. Through the highquality content offered in OSA Journals and conference proceedings, more than 180,000 scientists, PhD students and business leaders from 175 countries gain the confidence needed to power studies, shape real-world applications and accelerate achievements.

OSA offers flexible subscription options for accessing our content.

Contact us at elec@osa.org to acquire this high-quality content for your institution. 


\section{IDENTIFIER SERVICES}

WHERE DISCOVERY BEGINS!

Bowker\% Identifier Services provides you with the resources to make your titles more discoverable. Whether you area new self-published writer or an established author.

Once you begin this journey. you will be connected to the produts we provide to libraries, publishers, and booksellers worldwide.

THE OPPORTUNITIES ARE ENDLESS!

Bowker has connected with readers for more than 140 years Let us help you make those connections!

60 TO WWW.MYIDENTIFIERS.COM TOLEARN MORE

\section{Bowker \\ a ProQuest" afflilate}

630 Central Avenue $\bullet$ New Providence, NJ 07974 • 888-310-7333 • www.bowker.com 

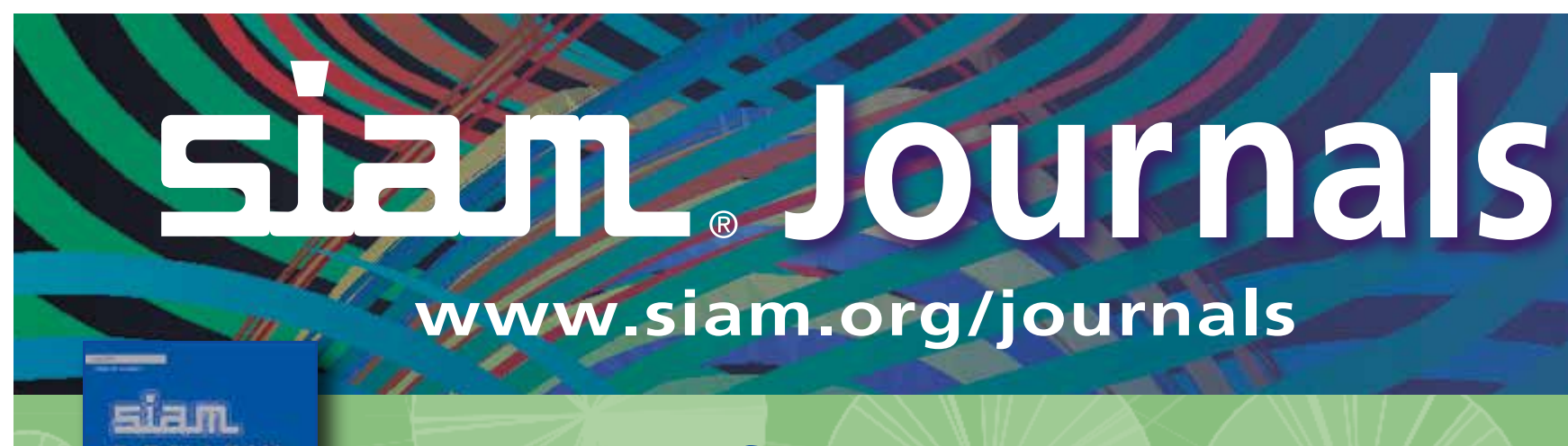

RE V IE W

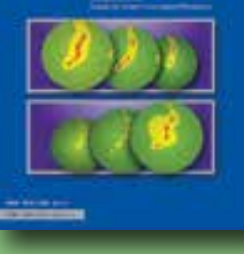

\section{Society for Industrial} and Applied Mathematics

Leading Applied Math and Computational Science
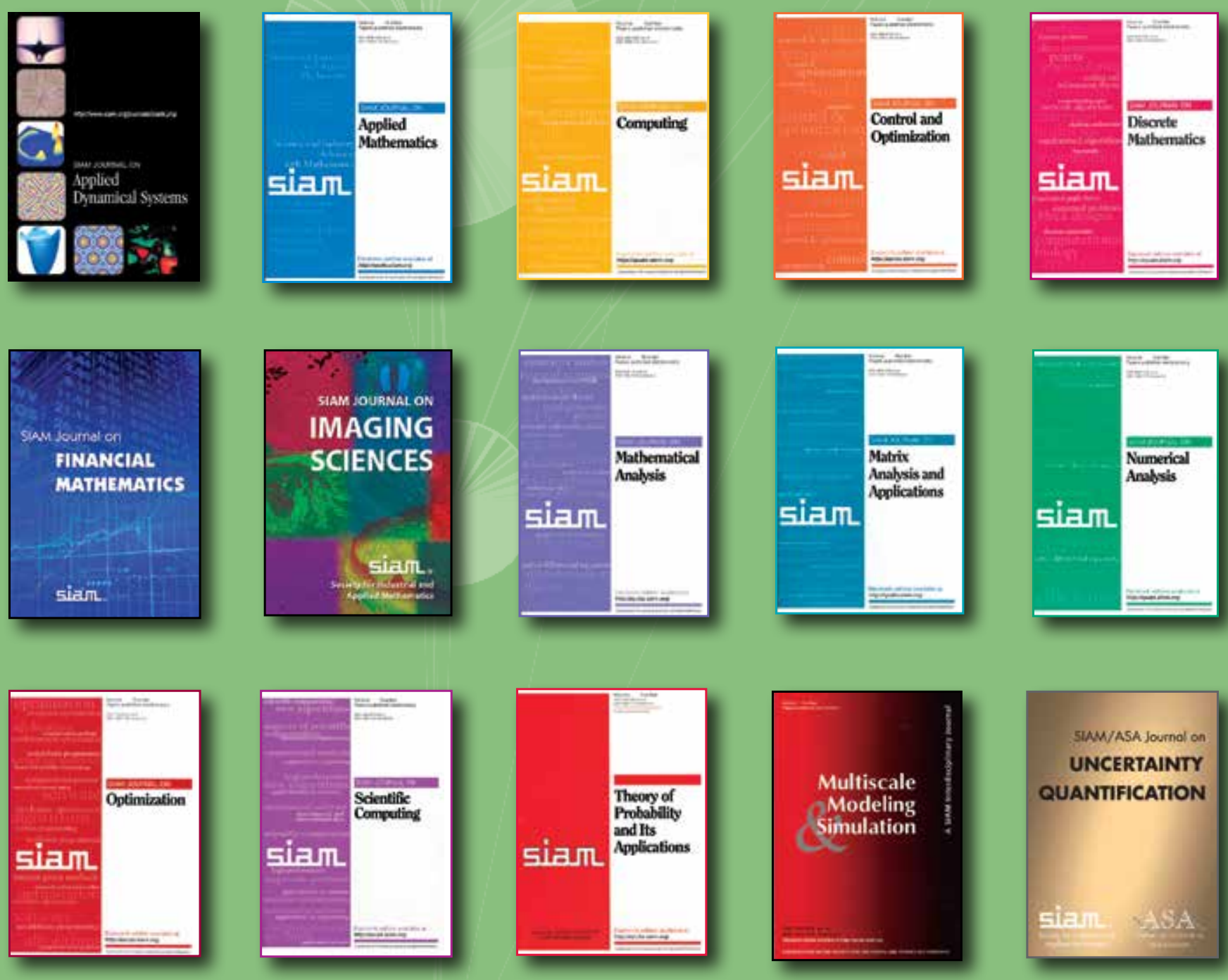

3600 Market Street, 6th Floor, Philadelphia, PA 19104-2688 USA
phone +1-215-382-9800 1 1-800-447-SIAM (toll free in USA and Canada)
fax +1-215-386-7999 - Email: subscriptions@siam.org

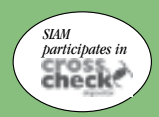




\section{ACSESSDL}

\section{Groundbreaking Agronomic and Environmental Research}

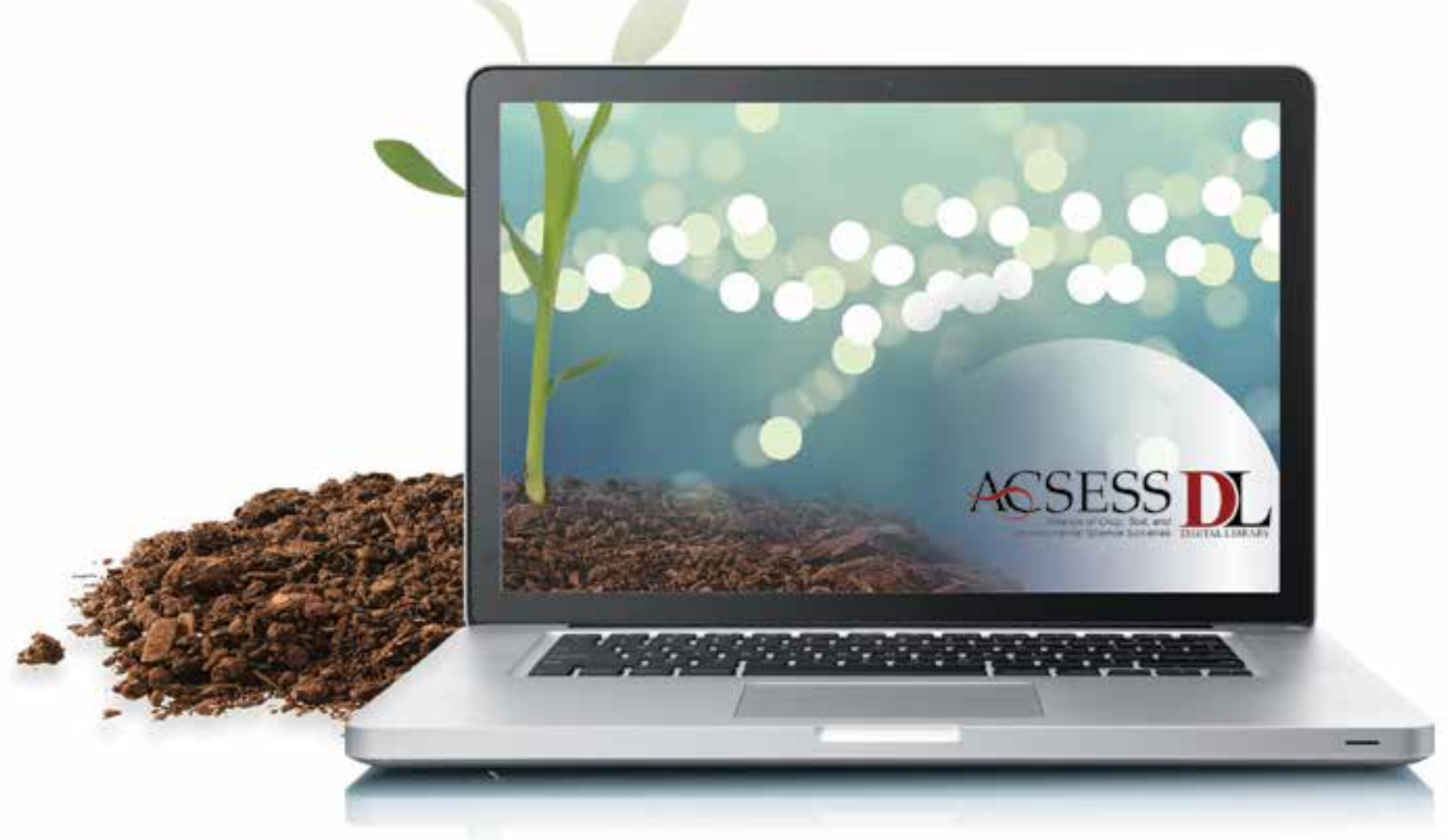

Where can you do innovative searches?

Where can you save articles you want to study?

Where can you share material with colleagues or students?

Where can you find conference presentations?

Where can you find citation data to manage your research?

All journals. All books. All magazines. All archives. All Here.

The ACSESS Digital Library is a complete collection of content as published by the American Society of Agronomy, Crop Science Society of America, and Soil Science Society of America. The Digital Library makes it possible to browse research, comment on, and share all of our published literature in one convenient place. 


\section{casalinie-content}

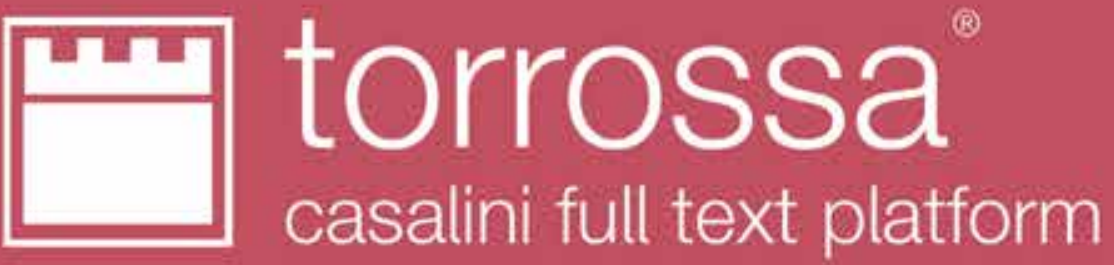

Exclusive, original-language scholarly content in the Humanities and Social Sciences

from Italy, Spain, France and Portugal available in a variety of purchasing options

\section{www.torrossa.it}

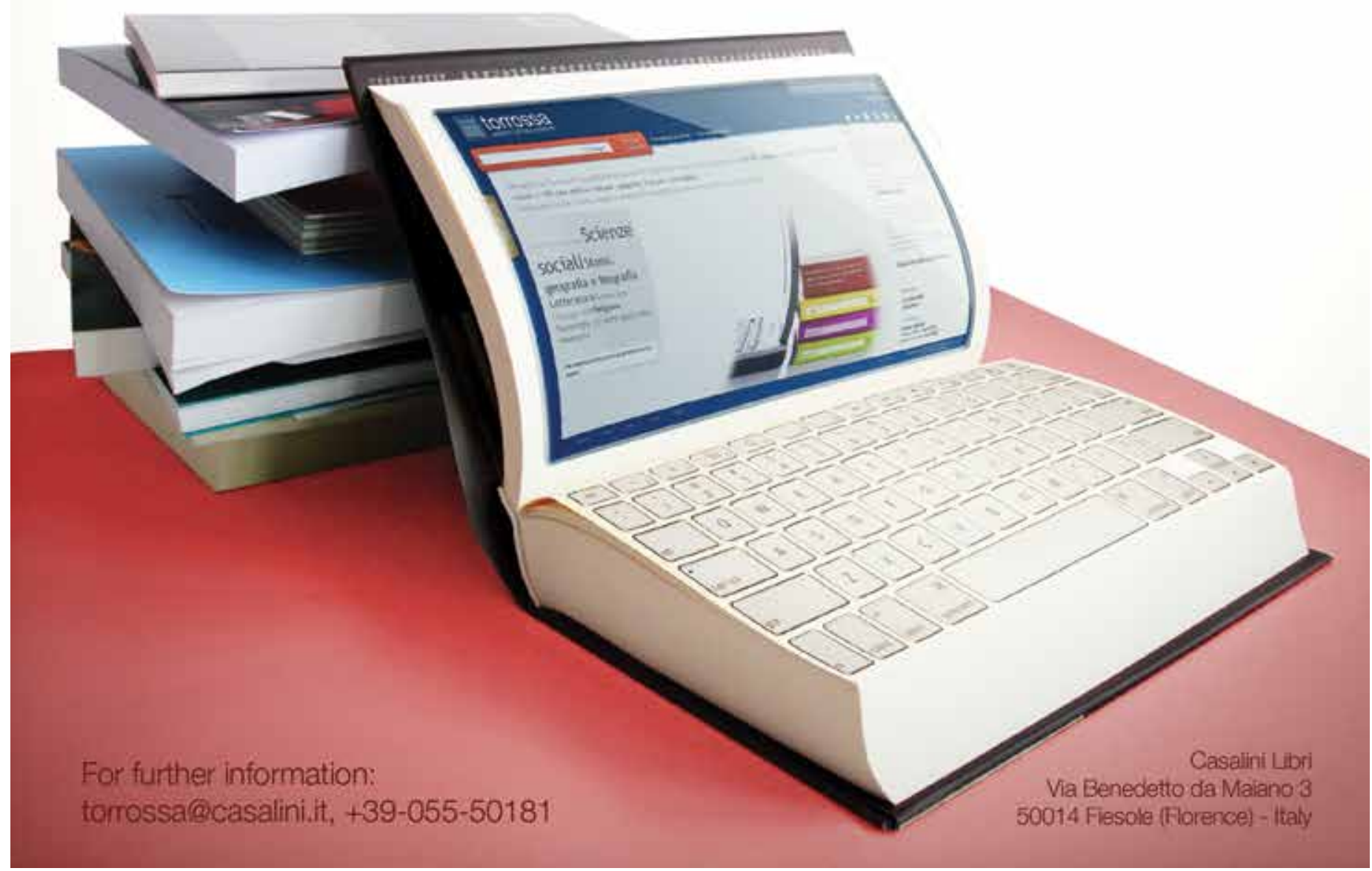




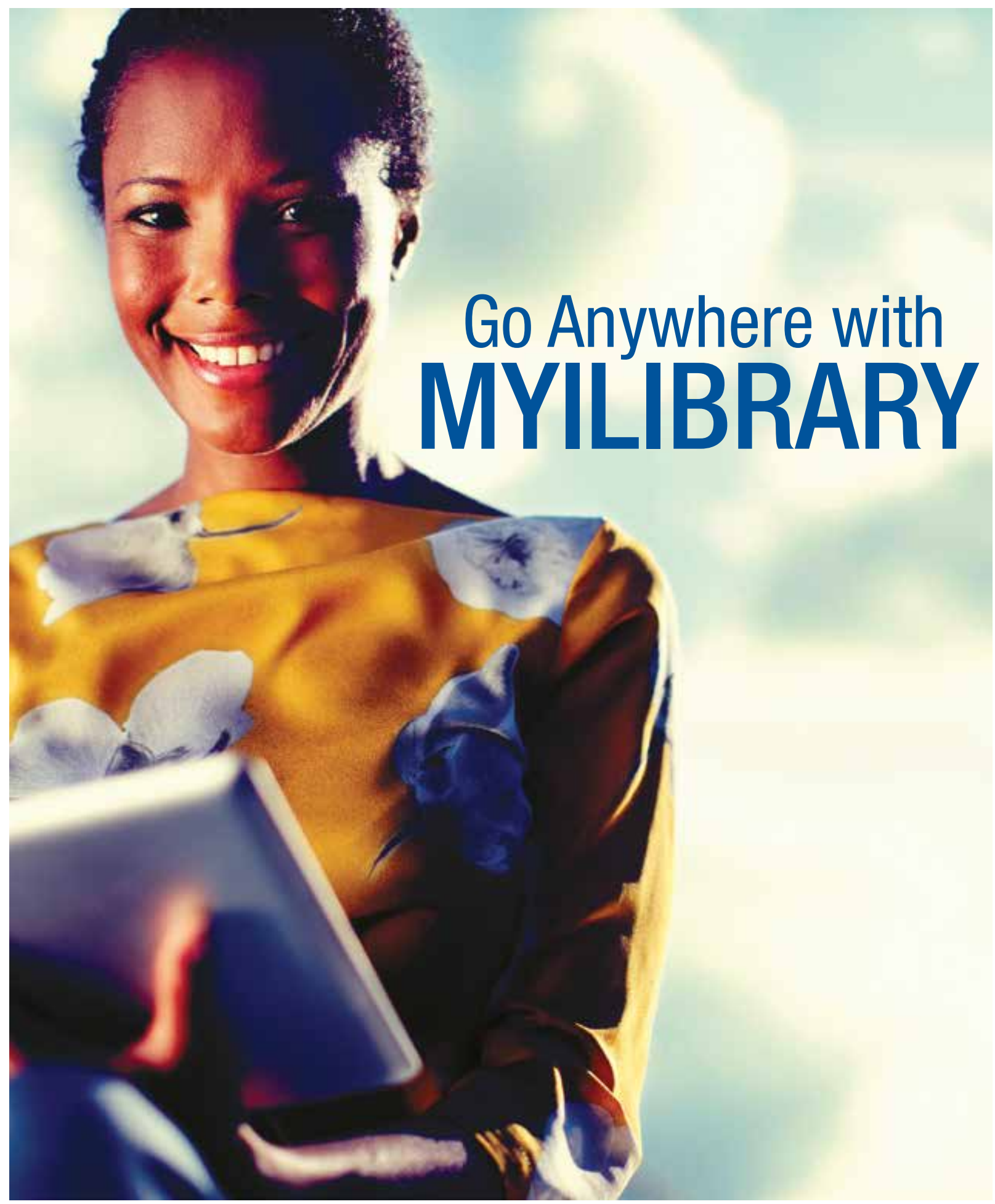

Get access and convenience from MyiLibrary with titles from leading academic publishers. Students, professors, and researchers can take their books wherever they go. Find which borrowing model works best for you. You'll like what you see.

Find more at www.ingramcontent.com/libraries

VISIT WITH INGRAM COUTTS AT THE CHARLESTON CONFERENCE AT TABLE \#63. 


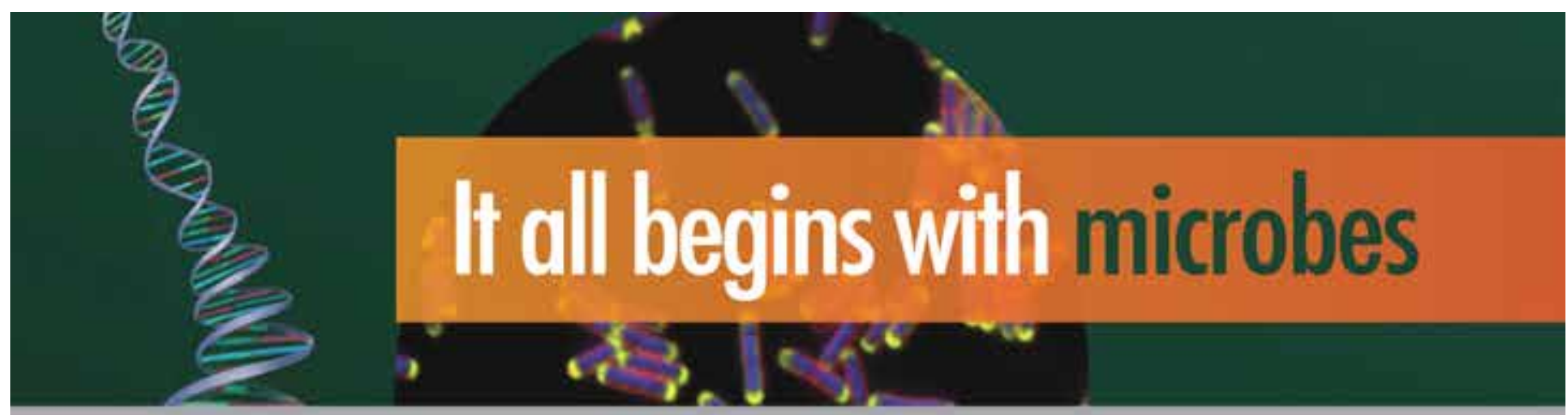

\section{Introducing the American Society for Microbiology Press eBooks collection}

ASMscience, the American Society for Microbiology's content platform, includes 200+ peer-reviewed books (frontlist and backlist) on all aspects of microbiology.

Subject areas span:

\section{Applied and Industrial Microbiology} Bacterial Pathogenesis Clinical Microbiology Environmental Microbiology Food Microbiology Fungi and Fungal Pathogenesis Immunology

Microbial Genetics and Molecular Biology Viruses and Viral Pathogenesis

General Interest History of Science
ASMscience eBooks feature:

Unlimited simultaneous use by authenticated patrons No digital rights management; unlimited saving and printing Chapter-level downloading and printing Content provided as PDFs by chapter Personalization available that enables saved searches and alerts Semantic content enrichment by TEMIS Perpetual access or subscription model pricing COUNTER-compliant statistics available Free MARC records available Interlibrary loan permitted Fully Indexed in web-scale discovery services Integrated searching with ASM Journals
Make an Informed Decision: Try it out for free! Invite your faculty members, key researchers, and library staff to review the breadth and depth of the collection We guarantee that the ASMscience eBook collection addresses every facet of microbiology.

1] Interested? Contact Mark Monfasani at +1(617) 395-4069 or mmonfasani@pcgplus.com 
REFWORKS FLOW

BY PROQUEST ${ }^{\circledR}$

fy

ENABLE RESEARCHERS TO

COLLECT, USE, SHARE

AND CITE RESEARCH

\section{START HERE}

\section{LEARN MORE ABOUT REFWORKS FLOW BY PROQUEST!}

Imagine a world where researchers have one place to interact with references AND full text documents, accessible from anywhere, anytime.

THAT'S FLOW.

Designed for researchers of all levels, getting started with Flow is quick and it's really easy to use, yet powerful in what it can do for research. There's nothing to install, and existing references within other programs can easily migrate to Flow with one click. Libraries can be assured in knowing that Flow is sensitive to copyright, even while references and full text from major databases and the web are captured. Users can collaborate on document collections, including the ability to annotate the documents within collections, and utilize the 3,000 citation styles - or create one of their own. And of course, there's unsurpassed customer support for librarians as well as users.

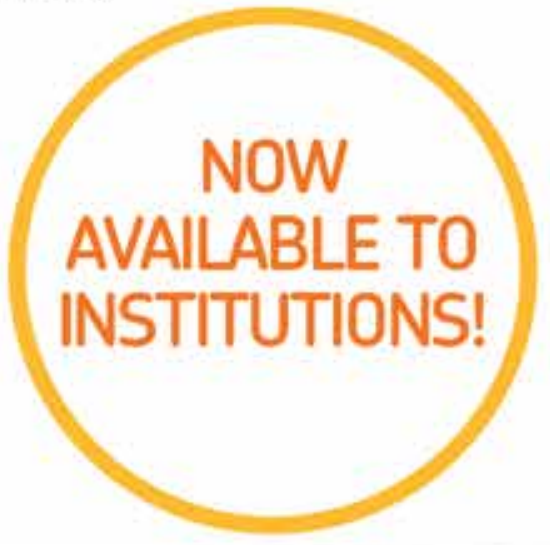

www.proquest.com/go/flowwebinar

789 E. Eisenhower Parkway • P.0. Box 1346 • Ann Arbor, MI 48106-1346 • USA 800-521-0600 - uww.proquest.com 


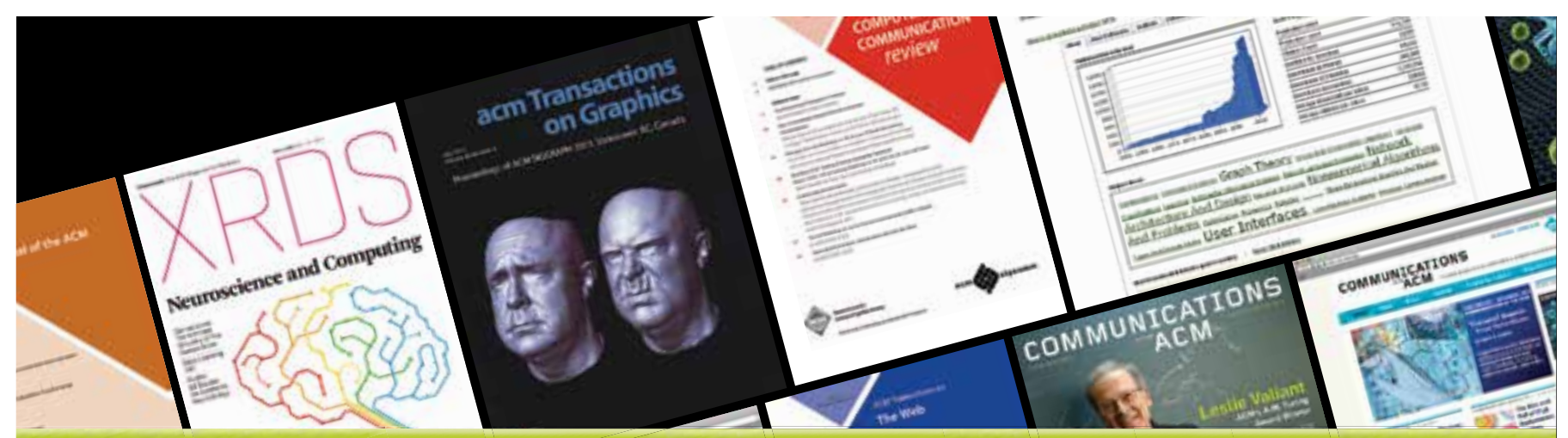

The Ultimate Online Resource for Computing Professionals \& Students

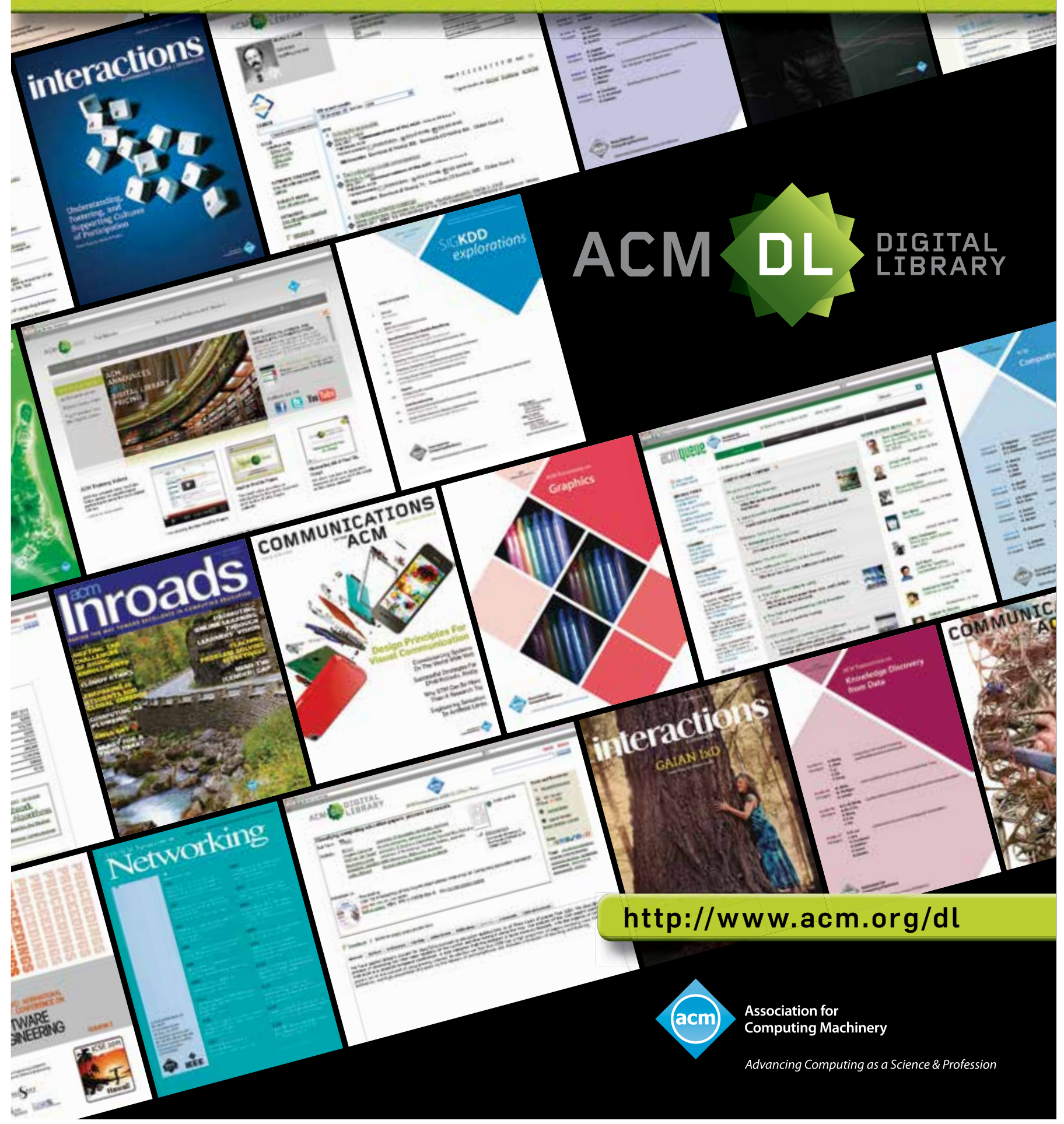


How does the 促 政 work for

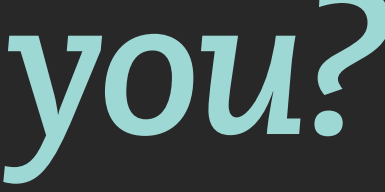

Promotes the study of language and literature

Publishes your scholarship

Hosts an annual convention where you can share your work

Compiles the Job Information List

Creates opportunities for scholarly interaction-visit the new MLA Commons
The Modern Language Association is a community of nearly 28,000 members dedicated to strengthening the study and teaching of language and literature. The MLA makes it possible for you to

- search the MLA Job Information List at no charge

- read reports and surveys issued by the MLA on the job market, enrollments, evaluating scholarship, and the state of scholarly publishing

- benefit from public outreach activities, including the popular MLA Language Map

- download the Academic Workforce Advocacy Kit, a tool for helping improve conditions for teachers and students

- access the MLA Handbook Web site and FAQs about MLA style

Become an MLA member at www.mla.org and receive the following benefits:

- subscriptions to PMLA and the MLA Newsletter

- access to directories of members and departmental administrators

- a $20 \%$ discount on all MLA titles

ability to read the ADE Bulletin or ADFL Bulletin online and search bulletin archives if your department is a member of the Association of Departments of English (ADE) or the Association of Departments of Foreign Languages (ADFL)

- the MLA Directory of Periodicals, a searchable database that provides submission requirements, editorial addresses, and subscription information for over 4,000 journals in the humanities

Three easy ways to join:

$\Delta$ Visit www.mla.org.

$\Delta$ E-mail membership@mla.org to request a membership packet.

A Call 646 576-5151.

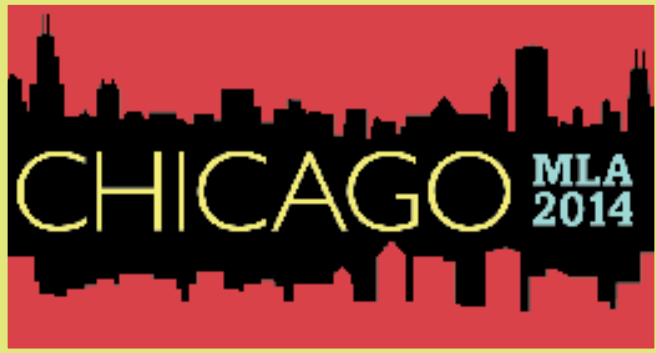

The MLA Annual Convention

9-12 January 2014 in Chicago

featuring the presidential theme Vulnerable Times

Join us at the largest gathering of teachers and scholars in the humanities for

- roundtables, workshops, and discussion

- special presentations featuring renowned thinkers, artists, and critics in conversation

- local excursions for registrants

2014 members receive reduced rates and special discounts for the 2014 convention in Chicago. Visit www.mla.org/convention for more information.
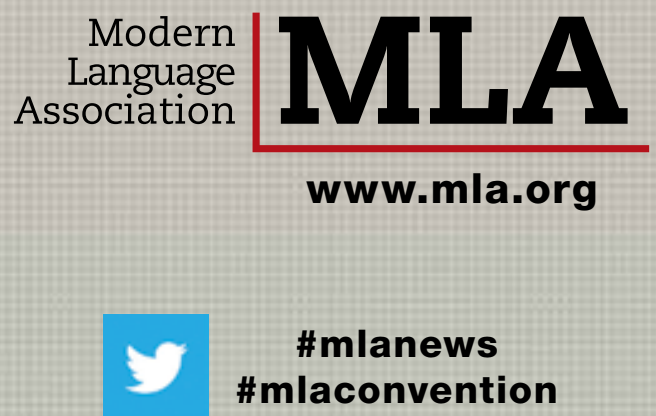


\section{CAMBRIDGE}

\section{Key Facts About Cambridge's eBook Offerings}

\section{Visit booth \#69 at the 2013 Charleston Conference to find out more!}
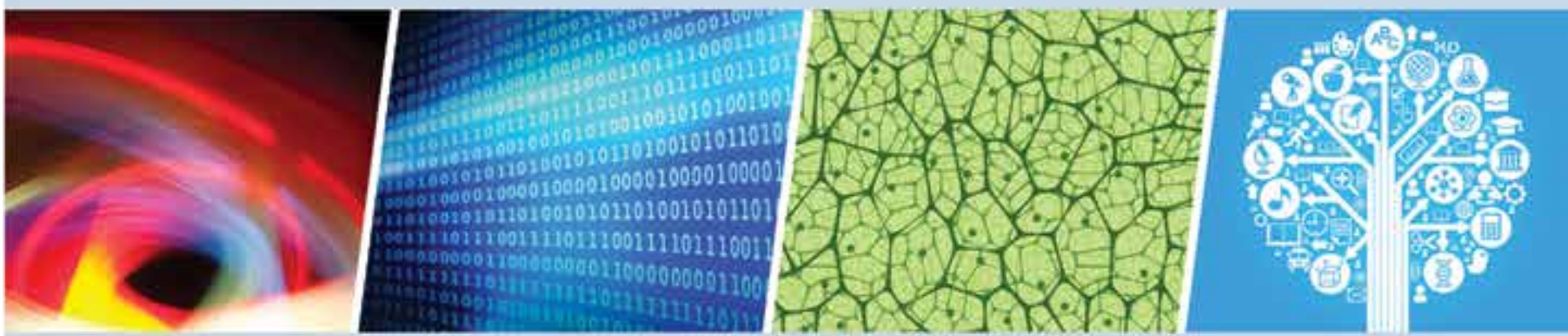

1) Advance Orders for New Titles Prepay once and automatically receive access to newly published titles added during the calendar year.

(3) Title-by-Title Purchasing Simply choose 25 titles for your first order. After that, there are no minimums and you are free to select individual titles.
(2) Simultaneous Electronic and Print Publication

New releases cleared for e-publication are made available every month on the platform simultaneously with print publication.

4 Custom Collections

Collections can be created by subject area, publication year, or series.

\section{CAMBRIDEE BDOKS ONLINE}

\section{UNIVERSITY PUBLISHING ONLINE}

Global scholarship redefined

University Publishing Online features eBooks from the world renowned publishing programs of Cambridge's partner presses such as Boydell \& Brewer and Mathematical Association of America. These titles are fully integrated with the Cambridge Books Oriline Platform.

Visit universitypublishingonline.org to find out more.

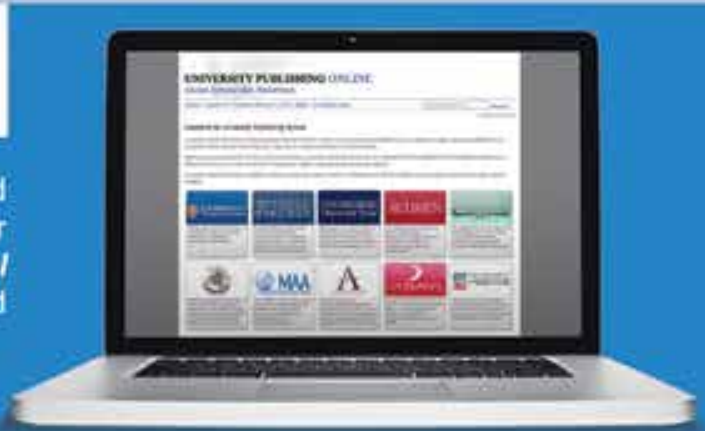

For more information, please contact us at online@cambridge.org. 


\section{Maney}

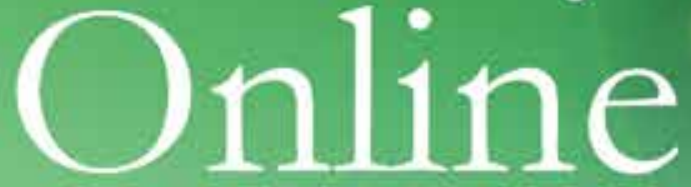

Maney Publishing's new

online journal platform

\section{Launching soon in 2013}

All Maney journals currently hosted on ingentaconnect will soon be moving to our new journal platform, Maney Online

Maney Online, powered by Atypon's Literatum platform, will bring greater functionality and flexibility to the online publication of our journals.

We are working hard to ensure a smooth and seamless transfer from ingentaconnect to Maney Online, with minimal disruption for our customers.
What can you expect from Maney Online?

- straightforward access to content

= an intuitive user interface

. advanced search capabilities

- popular research at your fingertips

" recommended articles tailored to you

For full details visit www.maneypublishing.com/maneyonlinefaqs 


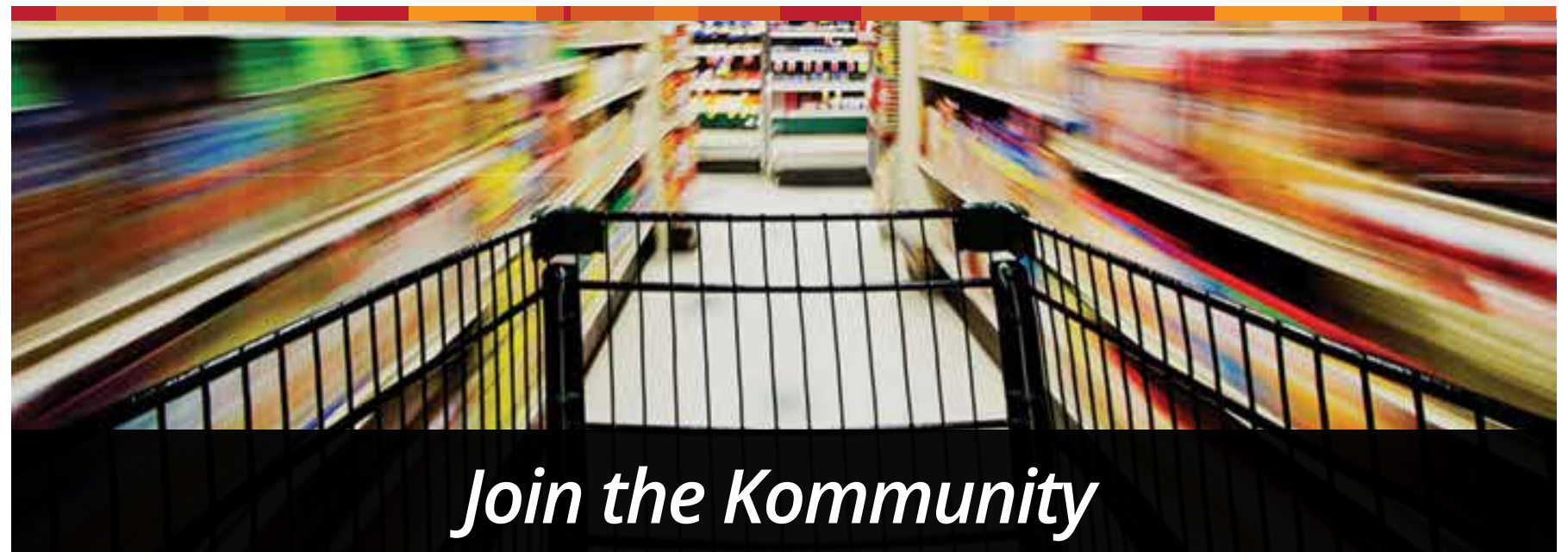

The fastest growing academic online video platform in North America

Kanopy collaborates closely with librarians around the world to solve the video problems today's librarians face:

Award-winning Platform

Branded video libraries, LMS

integration, clip-making,

captions, commentary.
Search and Find Service

Can't find a video you need to

stream? Email our team to track

down 'hard to find' films.

\section{Sophisticated Analytics}

Monitor detailed viewing

behavior so you are empowered

to make educated ROI decisions.

Our catalog of over 20,000 videos is available to license à la carte and includes the following collections:

\section{Documentary}
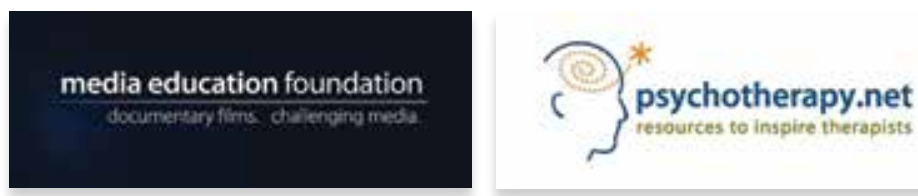

plus

hundreds more...

\section{Patron Driven Acquisition The first and only video platform to offer true PDA!}

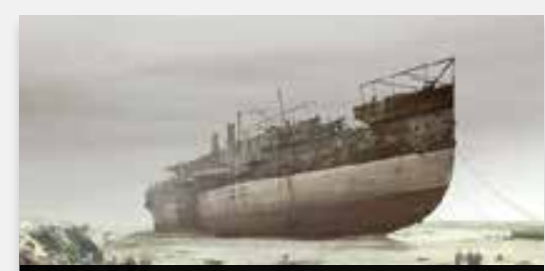

Seven Wonders by $B B C$
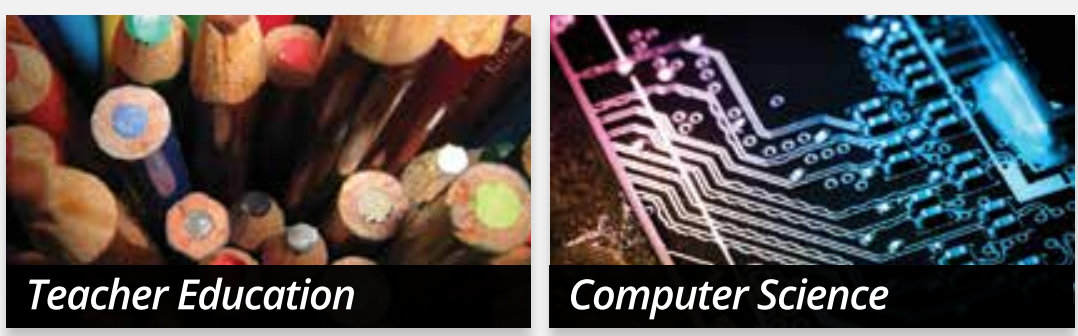

Meet us at National Media Market and the Charleston Conference 2013

Join the Kommunity! VIIIT: www.kanopystreaming.com EMAl: kanopy@kanopystreaming.com 


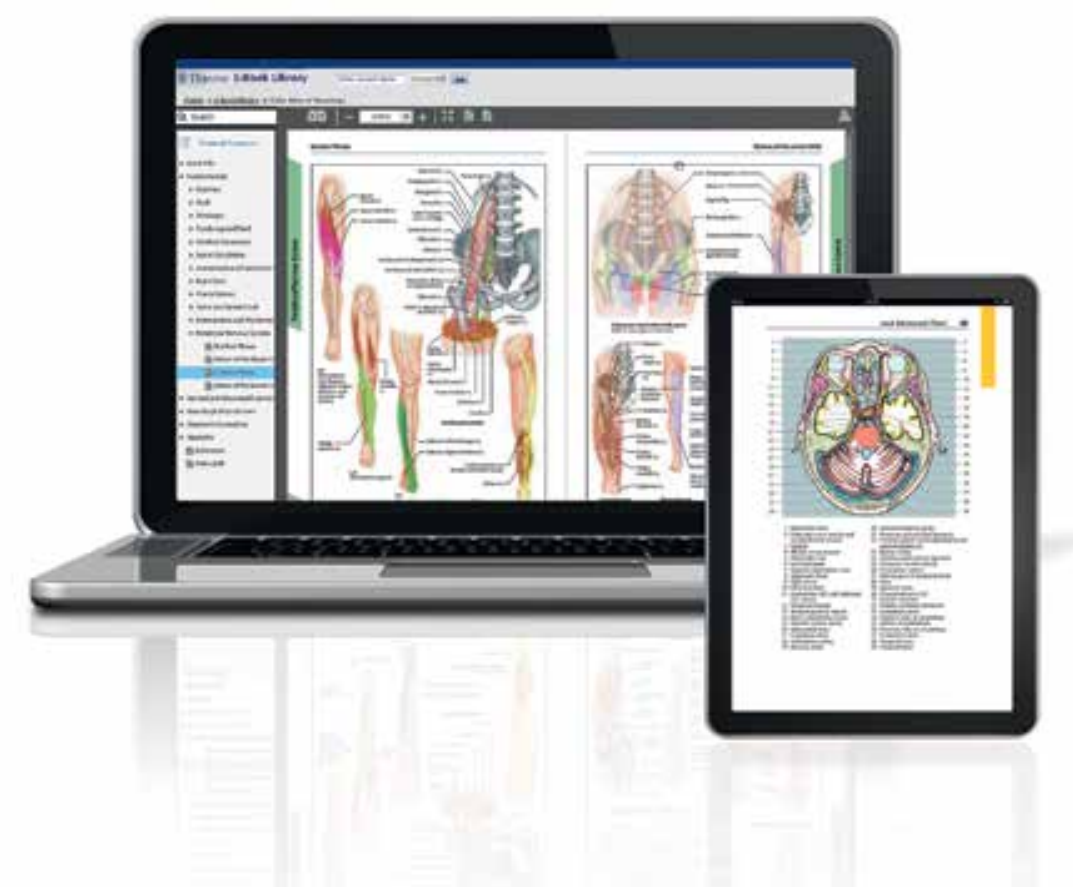

\section{Our educational solution}

\section{Thieme E-Book Library}

\section{Your resource of choice for learning, review, and research in medicine and the life sciences}

The Thieme E-Book Library offers unlimited concurrent online access to a collection of fully downloadable medical textbooks and color atlases.

It is the perfect learning solution for students in medicine and the allied health sciences comprised of anatomy, basic sciences, clinical sciences, radiology and physical therapy textbooks.

For more information and a free trial please visit www.thieme.com/tebl

\section{Our clinical solution}

\section{Thieme Clinical Collections}

\section{The prime resource for essential clinical E-Books}

Thieme Clinical Collections provides online access to Thieme's renowned book program in clinical medicine and is available to purchase on a perpetual access \& ownership licensing model.

The Collections feature an impressive selection of titles in neurosurgery, radiology, dentistry, orthopedic surgery, otolaryngology, audiology, neurology, internal medicine, ophthalmology and are essential for residency, fellowship, and clinicians to use in everyday practice.

Collections are available for each publication year; the 2014 front list is available for advance purchase.

For more information and a quote please visit www.thieme.com/tcc

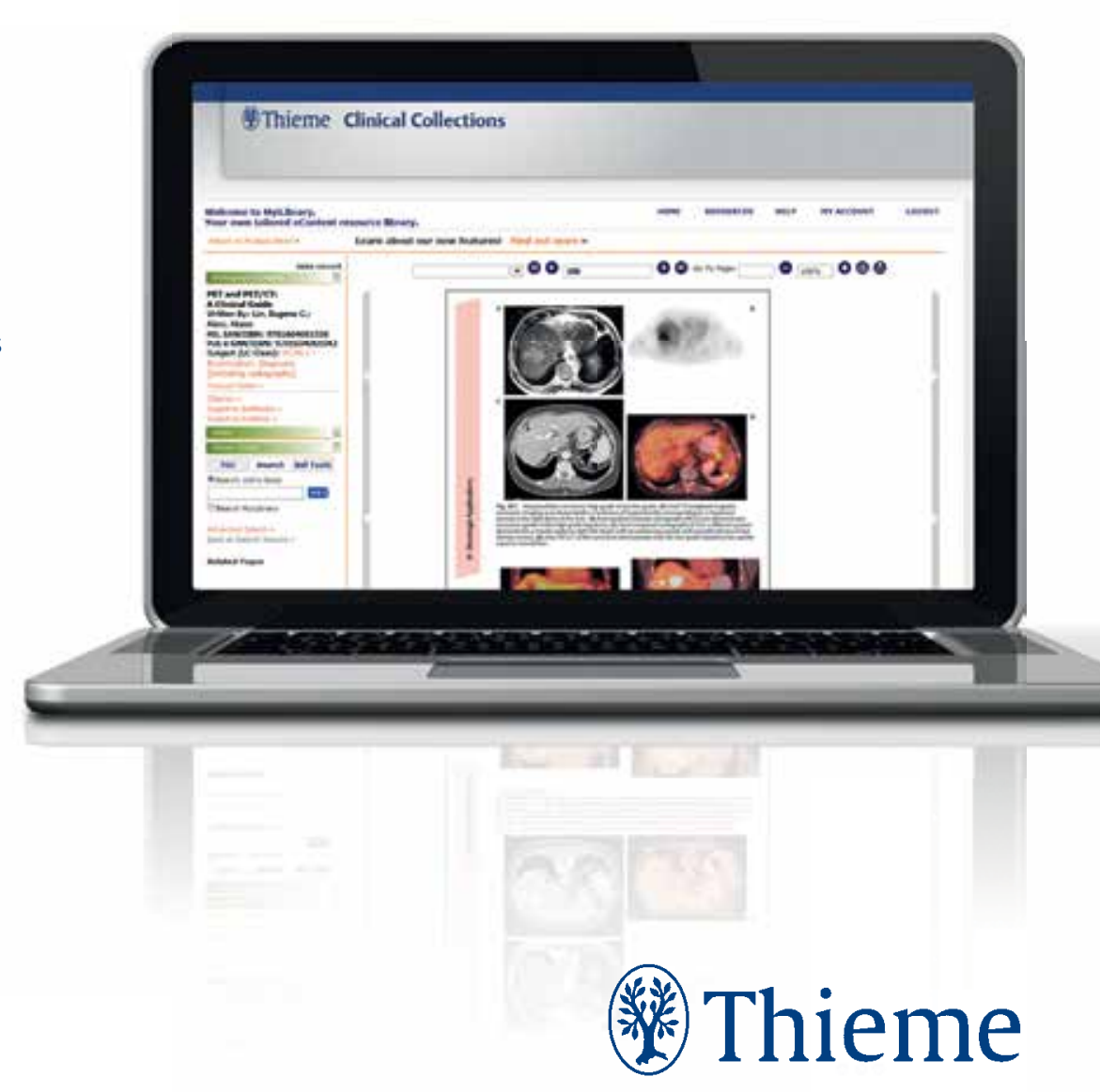




\section{Digital \\ Horary}

SPIEDigitalLibrary.org

\section{The world's largest collection of optics \& photonics research}

For more information visit SDLinfo.org

"The SPIE Digital Library gives access to over 50 years of the highest quality applied optics and photonics research; a valuable addition to any science and technology collection."

-Randy Reichardt, Librarian, University of Alberta

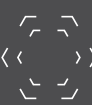

\llcorner\lrcorner

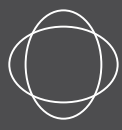

Biomedical Optics

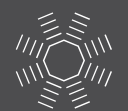

Communications

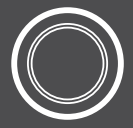

Defense

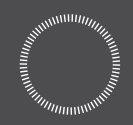

Energy

\section{NEW}

40,000 papers added back to

Vol. 1 (1962) 


\section{ANNUAL REVIEWS}

Celebrating 80 Years of Publishing Excellence

VISIT

US AT THE CHARLESTON

CONFERENCE

VENDOR

SHOWCASE

Annual Reviews intelligently synthesizes critical literature in the Biomedical, Life, Physical, and Social Sciences, including Economics. Our editors and authors are premier researchers in their fields. Your patrons can rely on Annual Reviews to assess the available research and deliver the ideas that matter, to cut out the noise, and to meet their research needs efficiently.

\section{ANNUAL REVIEWS AVAILABLE ON MOBILE DEVICES. USERS CAN NOW:}

- Browse journals, abstracts, and articles

- Search journals by keyword, author or title

- Read full-text and forthcoming articles (personal or institutional subscription required)

- View and search references

Visit www.annualreviews.org from a mobile device to learn more.

\section{SECURE ACCESS FOR YOUR PATRONS TODAY.}

Visit www.annualreviews.org or email sales@annualreviews.org.

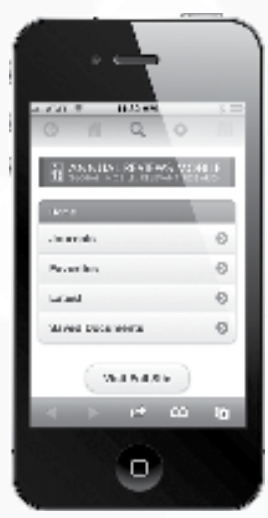

\section{NEW JOURNALS:}

\section{ANNUAL REVIEW OF ANIMAL BIOSCIENCES}

Complimentary online access available through February 2014. Purchase now to secure permanent data rights to Volume 1.

Launching in 2014 with complimentary online access to the first volume for the first year:

ANNUAL REVIEW OF STATISTICS AND ITS APPLICATION (January) ANNUAL REVIEW OF VIROLOGY (September)

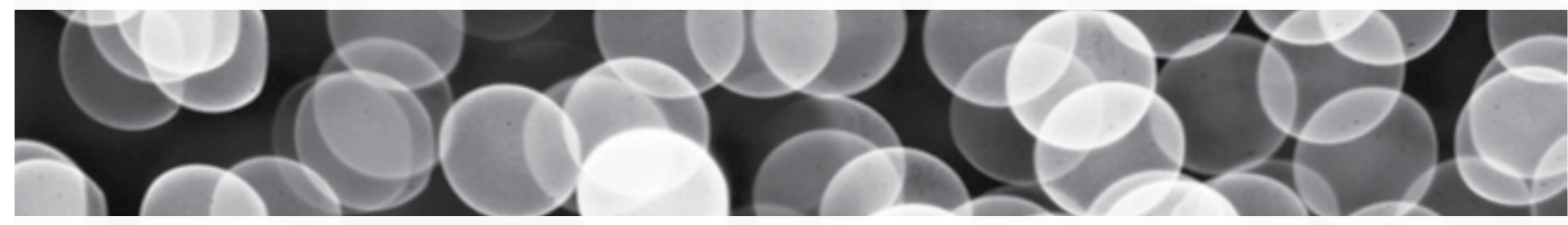

ANNUAL REVIEWS | Global. Mobile. Relevant Research.

Tel: 800.523.8635 (US/CAN) | Tel: 650.843.6647 | Fax: 650.424.0910 | Email: sales@annualreviews.org 


\section{AMERICAN INDIAN HISTORIES AND CULTURES}

Sources from the Edward E. Ayer Collection at The Newberry Library, Chicago

\section{A major new digital resource containing material from one of the strongest archival collections on American Indian history in the world}

American Indian Histories and Cultures presents a unique insight into interactions between American Indians and Europeans from their earliest contact, continuing through the turbulence of the American Civil War, the on-going repercussions of government legislation, right up to the civil rights movement of the mid-twentieth century.

Documents digitized in full colour include:

- Manuscripts from the early 16 th to the mid-20th centuries

- Artworks including rare American Indian ledger art

- Speeches and petitions written by American Indians

- Diaries, essays, travel journals and ledger books from early European expeditions

- Correspondence, notes and minutes relating to important treaties

- Early linguistic studies and ethnographic accounts of American Indian life

- Thousands of photographs

- Historic maps and atlases

- Rare printed books

- American Indian newspapers from the 1960s-1990s

World:
Find Us:

@AdamMatthewGrp

facebook.com/TheAdamMatthewGroup 


\section{portlandcustomerservices \\ partners for success}

\section{Supporting Pu

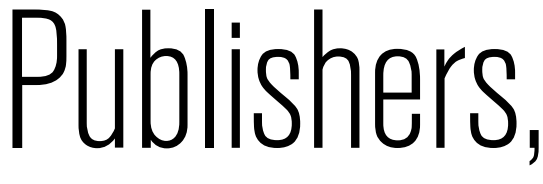 \\ Societies and \\ Associations}

- Journal subscription and book fulfilment

- Full membership services

- Scientific conferences and event organization

- Online journal hosting

- Content management and website hosting

- Association management, secretariat and treasury services

\section{www,portland-services.com kathy.law@portlandpress.com}




\section{AlP/Digital Archives}

Complete your collection of the world's best physical science research. Contact us today to find out how your scientists can benefit from:

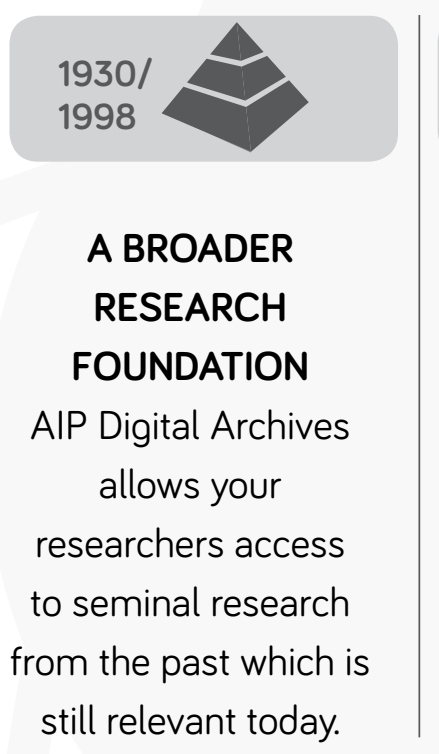

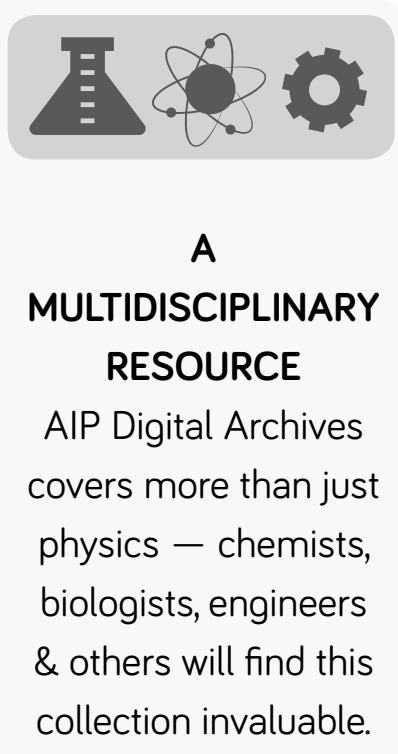

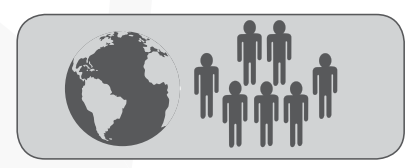

A GLOBAL COMMUNITY OF EXPERTS

Since 1930, AIP has been the premier publisher of the world's leading physical scientists.

\section{0 years of research}

\section{0,000 Articles}

3 Million

Downloads

in 2012

To learn more about our affordable tier pricing options, contact sales@aip.org. 


\section{$\|$ oword scientific Connecting Great Minds}

\section{New Electronic Major Reference Works}

Call 1-800-227-7562 or email wspc@wspc.com for free trials

\section{HANDBOOK OF CARBON NANO MATERIALS}

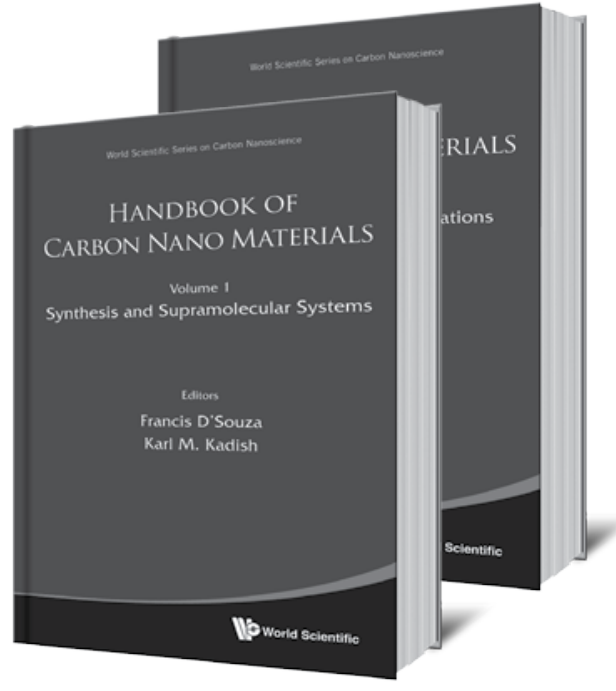

Volume 1: Synthesis and Supramolecular Systems Volume 2: Electron Transfer and Applications 978-981-4327-82-4 (ebook) US: \$ 494.00

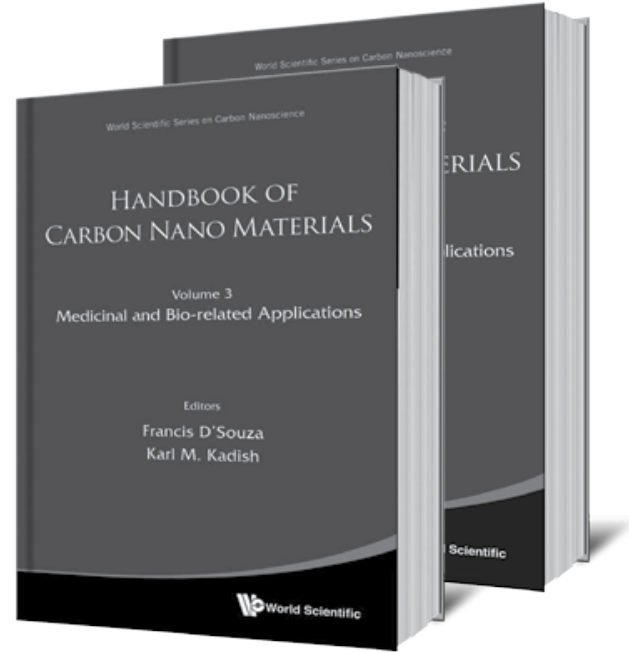

Volume 3: Medicinal and Bio-related Applications Volume 4: Materials and Fundamental Applications 978-981-4401-44-9 (ebook ) US: \$ 494.00

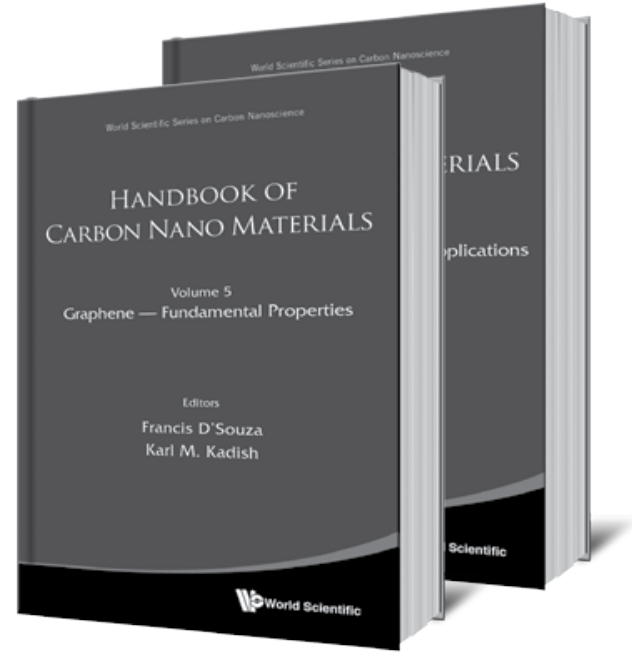

Volume 5: Graphene - Fundamental Properties Volume 6: Graphene - Energy and Sensor Applications 978-981-4566-70-4 (ebook) US: \$ 494.00

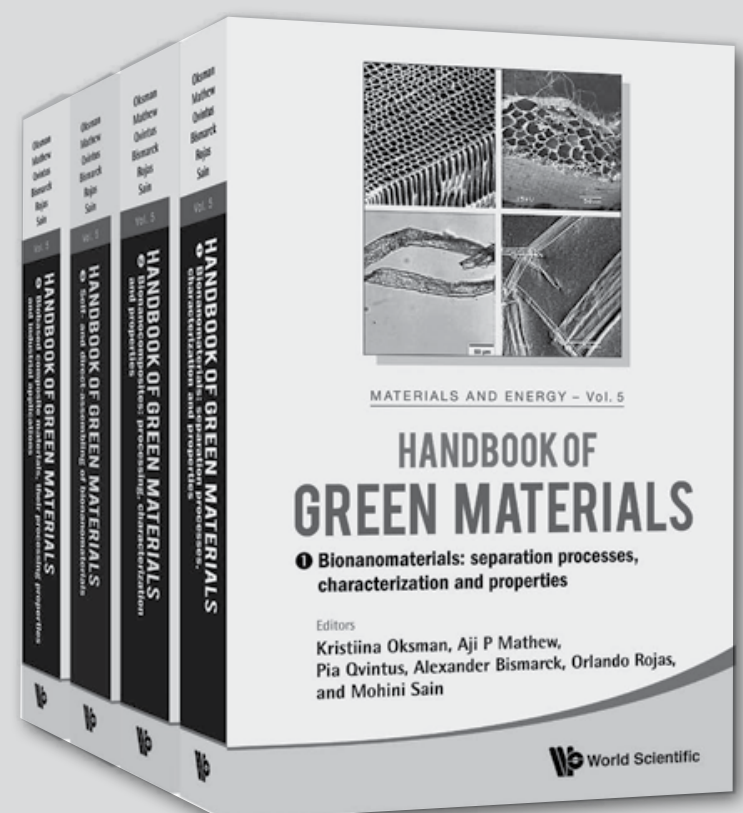

Materials and Energy - Vol. 5

HANDBOOK OF GREEN MATERIALS

Processing Technologies, Properties and Applications (In 4 Volumes)

Vol. 1: Bionanomaterials: separation processes, characterization and properties

Vol. 2: Bionanocomposites: processing, characterization and properties

Vol. 3: Self- and direct-assembling of bionanomaterials

Vol. 4: Biobased composite materials, their processing properties and industrial applications

978-981-4566-46-9 (ebook) US: \$ 2054.00 


\section{PsychiatryOnline.org}

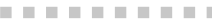

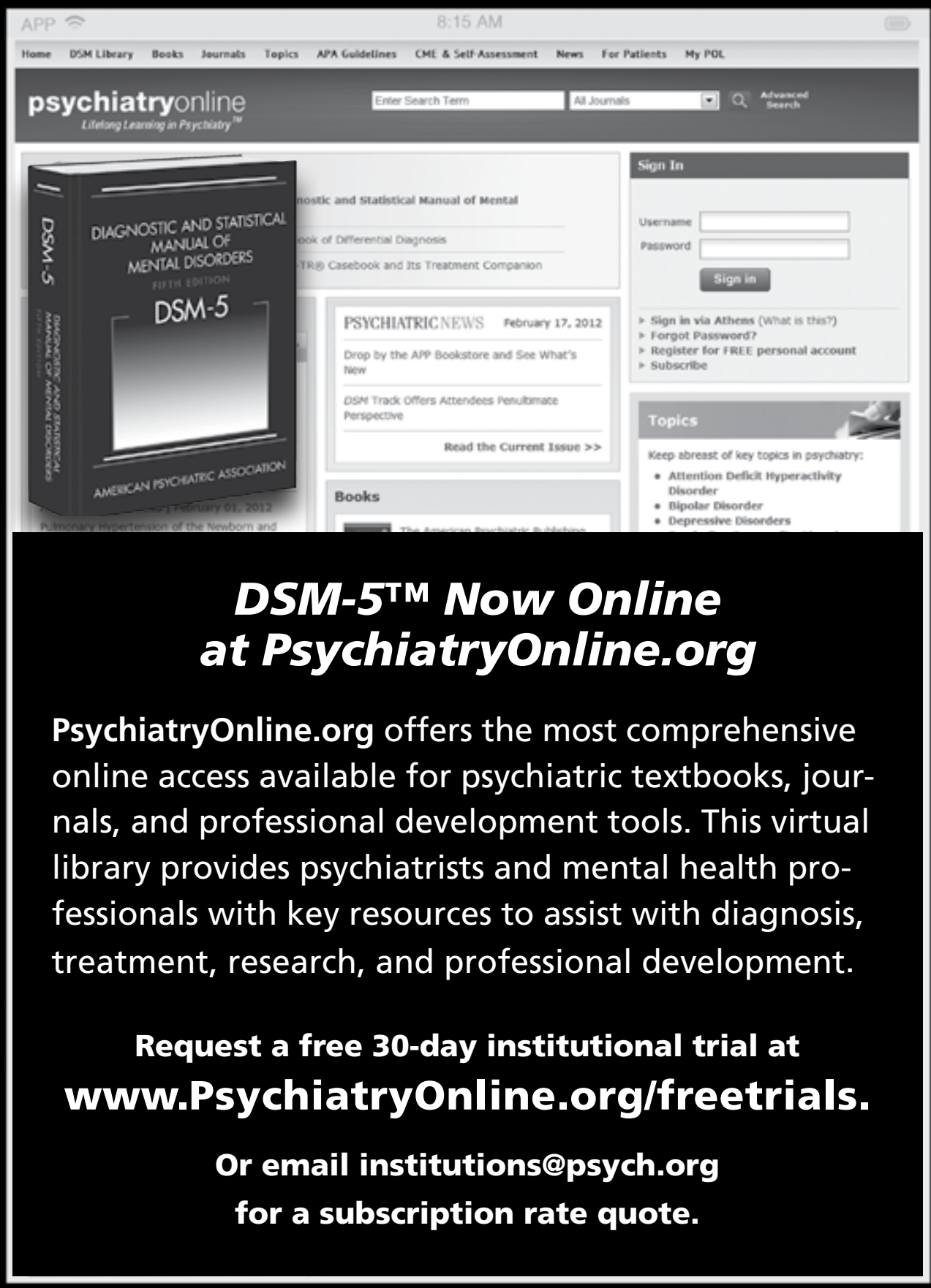

\section{American \\ Psvchiatric \\ Publishing}




\section{:? The ASME Digital Collection}

EXCELLENCE IN ENGINEERING

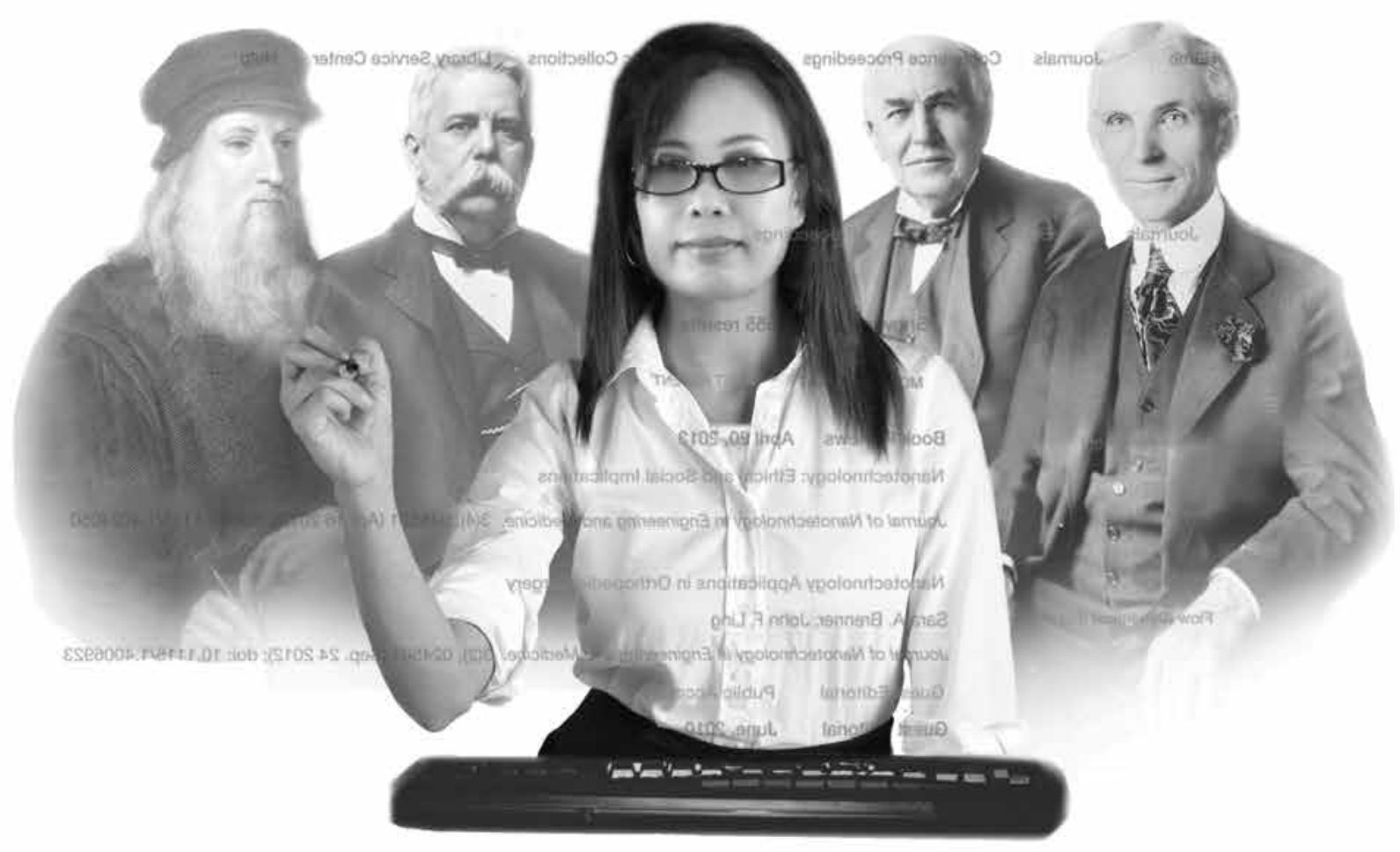

Journals $\mid$ eBooks $\mid$ Conference Proceedings

For more information about The ASME Digital Collection, Visit asmedigitalcollection.asme.org

To Subscribe, contact Warren Adams

Phone: 973-244-2223 Fax: 973-882-8113 Email: adamsw@asme.org

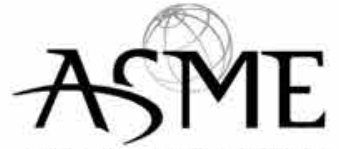


Aiming Science and Engineering with Analytics?!

When its Unsolvable - Search BEGELL DIGITAL LIBRARY!

\section{OVER 500,000 USERS* FROM}

\section{COUNTRIES EVERY MONTH}

Delivery to Your Choice of Devices: Mobile, iPad and Tablets

\section{WHY BEGELL DIGITAL LIBRARY?}

- Advanced Interface Functions on Taxonomy and Semantic Search

- High Impact Peer-Reviewed Content

- Extensive Properties Data and Latest Research
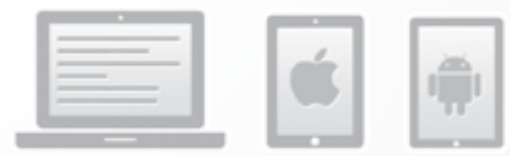

- Collections Selected by Emerging Research Area

www.begellhouse.com | www.dl.begellhouse.com 


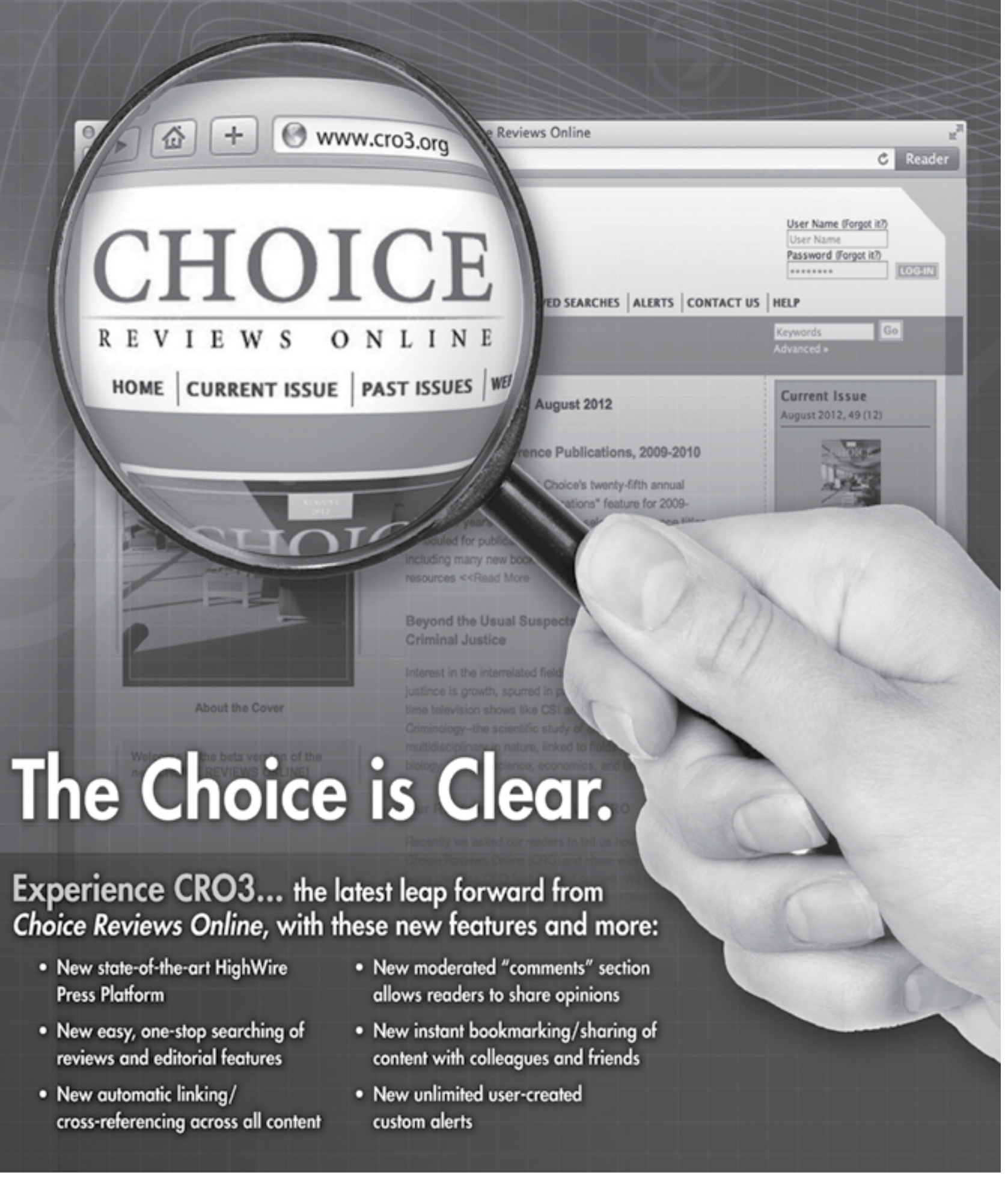

CRO3 is the perfect companion to a CHOICE print subscription

- Access to over 175,000 CHOICE reviews, all magazine content, and exclusive online features

- Download, print or email search results

- Create, save, print, email and download lists of selected tifles

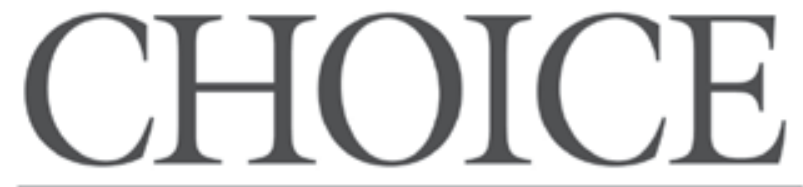

CURRENT REVIEWS FOR ACADEMIC LIBRARIES The Clear Choice is Choice Reviews Online - CRO3

To learn more about Choice Reviews Online, visit us at www.cro3.org 


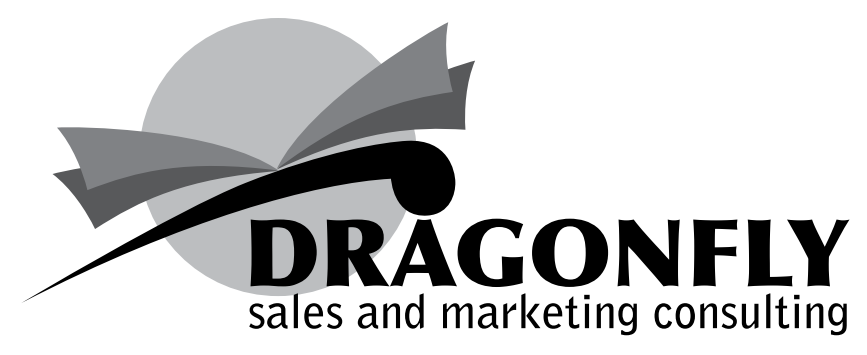

Dragonfly is an authorized sales agent for:

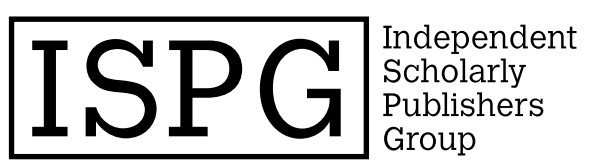

Highest quality research in the Life and Medical Sciences.

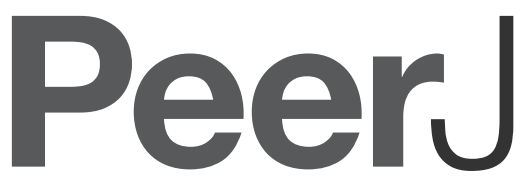

Open Access, Peer Reviewed, and Lifetime Memberships.

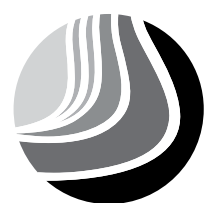

GeoScienceWorld

A one-stop shop and digital archive for earth science researchers.

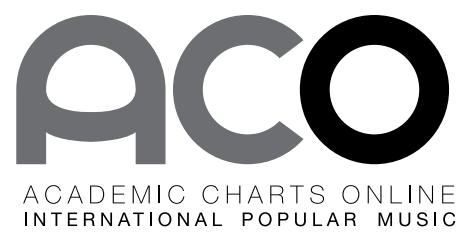

Quantifying the impact of music on culture

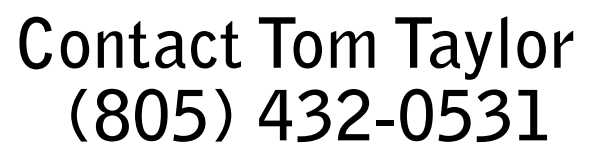

tom.taylor@dragonflypubservices.com

www.dragonflypubservices.com 


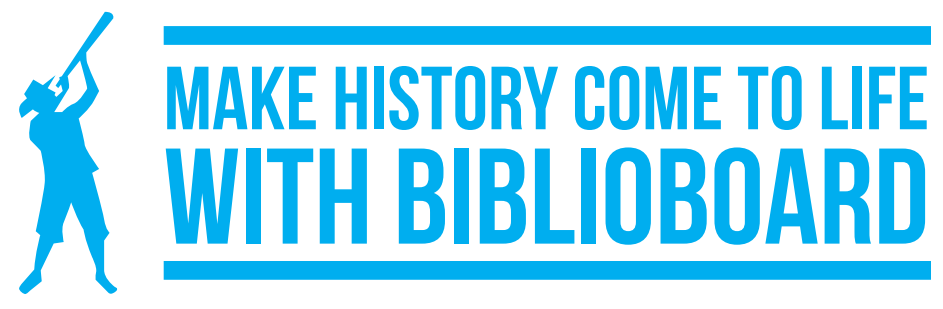

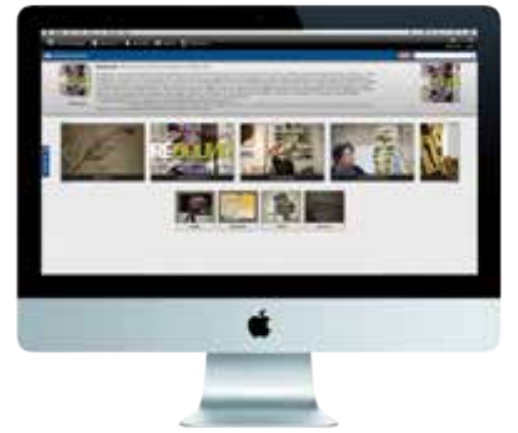

WEB

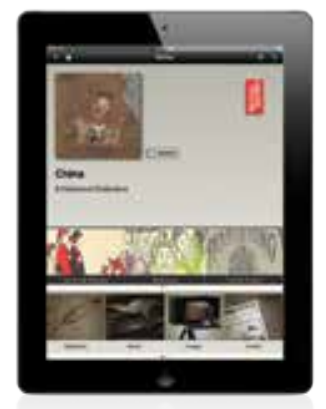

IPAD ${ }^{\circledR}$

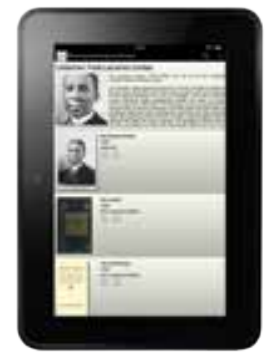

KINDLE ${ }^{\circledR}$

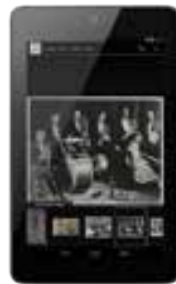

NEXUS ${ }^{\circledR}$

\section{\{CREATE\}}

Libraries and other cultural institutions around the world are using BiblioBoard Creator to build multimedia digital anthologies out of content in their special collections to serve the high expectations of today's tech-savvy patrons.

It's easy and lets professors, historians and curators in your community publish for free! Start making history today.

\section{\{CONNECT\}}

- 1-Click sync to native Apps for Apple iPad ${ }^{\circledR}$, Kindle Fire ${ }^{\circledR} \mathrm{HD}$ and Nexus $7^{\circledR}$

- Visually stunning presentation

- Intuitive, fast and easy to use

- Expertly curated content from the world's top libraries

- Millions of pages of primary source content including, maps, letters, pamphlets, ephemera, diaries, photos and more

- Streaming audio and video

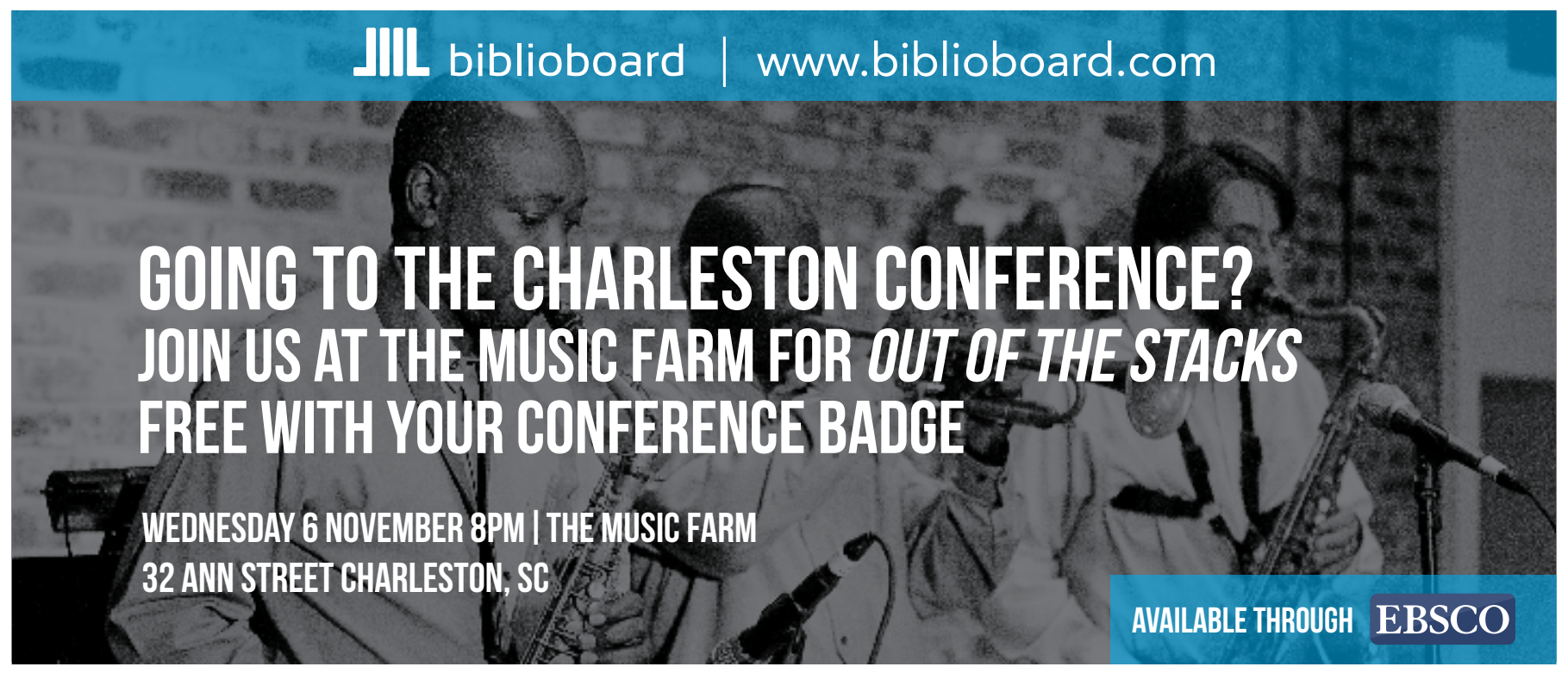




\section{Continuations and Standing Orders}

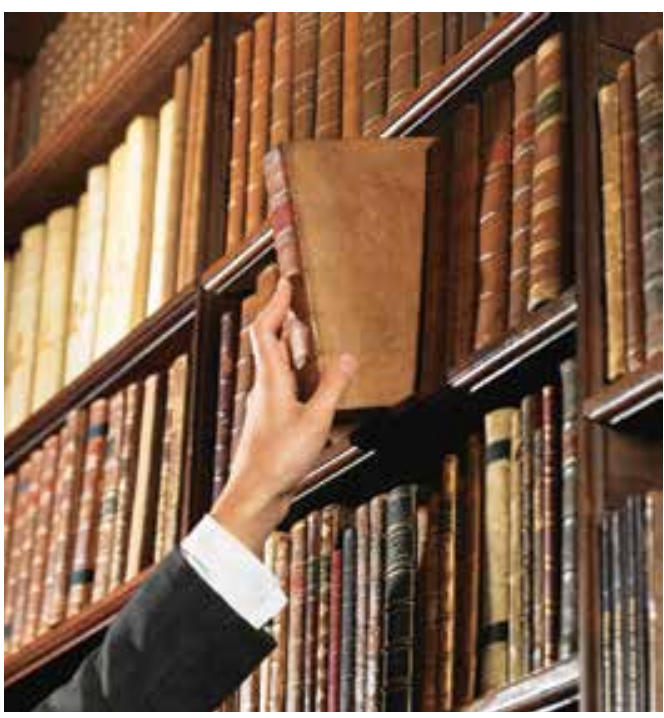

\section{Preface}

Continuations and standing orders represent a frustrating and time-consuming area of book acquisitions. Efficient management of continuations requires a staff knowledgeable in all aspects of standing order procedures, with prompt and accurate service being essential.

Midwest Library Service has been providing continuation and standing order programs to libraries for over three decades with the same commitment to high quality as our firm order service: prompt delivery, accurate invoicing, immediate reporting, convenient communications, and personal Library Service Representatives. Our reputation for excellence is well established and we invite you to place your continuations list with us.

\section{Scope}

Our Continuation \& Standing Order Service encompasses most series and continuations from U.S. publishers. Our services do not include supplying magazines, journals, or loose-leaf updating services.

\section{Procedure}

Our Continuation \& Standing Order Service incorporates both automated systems and personal surveillance. Instead of relying on the filing and ordering systems of the publishers, we place orders for specific volumes as books are due to be published. If the next item in a series is not received when scheduled, we initiate a new order for the same item. This procedure helps avoid potentially missed volumes and eliminates any dependence upon the publishers' fulfillment systems. If in-house information is not available on future volumes to be published, we call the publisher for future projections and publication schedules. This information is then used to update our new title records.

\section{Advantages}

1. Because of our method of ordering specific volumes, we are in regular communication with the publishers.

2. Our status reports are prompt and accurate and should eliminate library claims.

3. Specific claims from an individual library resulting in an updated status report will generate new status reports to all libraries ordering the same series.

4. We do not drop ship.

Quality service depends on good communications between the library and the jobber. Your personal Library Service Representative and our convenient communications provide easy access to us regarding your continuation orders. We invite you to try our service by sending us your next list of standing order titles.

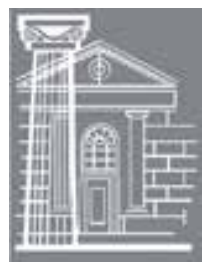

\section{Midwest Library Service}

11443 St. Charles Rock Road • Bridgeton, Missouri 63044-2789 • U.S.A.

www.midwestls.com

E-mail: mail@midwestls.com
Fax: 800-962-1009 • 314-739-1326

Phone: 800-325-8833 • 314-739-3100 